\title{
NBSIR $75-705$
}

\section{Thermal and Flow Characteristics of the ASTM E 84 Tunnel Test Method}

Jumes G. Quintiere and James W. Raines

Center for Fire Research

Institute for Applied Technology

National Bureau of Standards

Washington, D.C. 20234

September 1975

Final

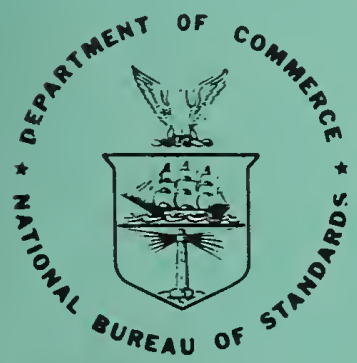

U S. DEPARTMENT OF COMMERCE

NATIONAL BUREAU OF STANDARDS 



\section{THERMAL AND FLOW CHARACTERISTICS OF} THE ASTM E 84 TUNNEL TEST METHOD

James G. Quintiere and James W. Raines

Center for Fire Research

Institute for Applied Technology

National Bureau of Standards

Washington, D.C. 20234

September 1975

Final

U.S. DEPARTMENT OF COMMERCE, Rogers C.B. Morton, Secretary James A. Baker, III, Under Secretery

Dr. Betsy Ancker-Johnson. Assistent Secretery for Science and Technology

NATIONAL BUREAU OF STANDARDS, Emest Ambler, Acting Director 



\section{CONTENTS}

Page

LIST OF FIGURES . . . . . . . . . . . . . . . . IV

LIST OF TABLES. . . . . . . . . . . . . . . . . V V

1. INTRODUCTION. . . . . . . . . . . . . . . 1

2. DESCRIPTION OF EXPERIMENTS. . . . . . . . . . 2

3. RESULtS AND ANALYSIS. . . . . . . . . . . . . . 3

3.1. Mass Flow Rate of Air . . . . . . . . . 5

3.2. Energy Balance. . . . . . . . . . . . 6

4. CONCLUSiONS . . . . . . . . . . . . . . 7

5. REFERENCES . . . . . . . . . . . . . 8

APPENDIX A. TABULATION OF DATA . . . . . . . . . . 9

APPENDIX B. SI CONVERSION UNITS. . . . . . . . . 20 
Page

Figure 1. Schematic of instrumentation. ( 1 in $=$ $0.0254 \mathrm{~m}, 1 \mathrm{ft}=0.3048 \mathrm{~m}) . .$. . .

Figure 2. Flame tip position as a function of time. (1 $\mathrm{ft}=0.3048 \mathrm{~m}$ ).........

Figure 3. Exit gas temperature as determined in the standard test for an energy release rating.

Figure 4a. Air mass flow rate of T374, nylon carpet. (1 $1 \mathrm{~b} / \mathrm{min}=0.00756 \mathrm{~kg} / \mathrm{s}) . . . .$.

Figure 4b. Air mass flow rate for T375, wood carpet. ( $1 \mathrm{lb} / \mathrm{min}=0.00756 \mathrm{~kg} / \mathrm{s}) . . . .$. .

Figure 4c. Air mass flow rate for T376, polypropylene carpet. $\quad(1 \mathrm{lb} / \mathrm{min}=0.00756 \mathrm{~kg} / \mathrm{s}) .$. .

Figure 4d. Air mass flow rate for T377, Nylon carpet (floor mounted). (l lb/min $=0.00756 \mathrm{~kg} / \mathrm{s})$.

Figure 5. Enthalpy flow rate at section $A$ for the calibration run. (l $\mathrm{Btu} / \mathrm{min}=17.57 \mathrm{~W})$.

Figure 6. Enthalpy flow rate at section B for the calibration run. (1 Btu $/ \mathrm{min}=17.57 \mathrm{~W})$.

Figure 7a. Net energy loss rate between sections A and $\mathrm{B}$ for the calibration run.

$(1 \mathrm{Btu} / \mathrm{min}=17.57 \mathrm{~W}) . . . . . .$.

Figure 7b. Net energy loss rate between sections $A$ and B for T374, nylon carpet. (1 Btu/ $\min =17.57 \mathrm{~W}) . . . . . . . .$.

Figure 7c. Net energy loss rate between sections A and $\mathrm{B}$ for T375, wool carpet. (1 Btu/min =

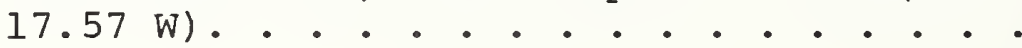

Figure 7d. Net energy loss rate between sections A and B for T376, polypropylene carpet. ( $1 \mathrm{Btu} / \mathrm{min}=17.57 \mathrm{~W}) . . . . . . .$. 
LIST OF TABLES

Page

Table 1. Description of Experiments . . . . . . . 4 Table 2. Classification Results . . . . . . . 5 Table A-1. Data Channel Code and Location. . . . . 10 Table A-2. Experiment No. 1: Asbestos-Cement Board, Calibration Run. . . . . . . . . . . . 11

Table A-3. Experiment No. 2: Polypropylene Carpet. . 12 Table A-4. Experiment No. 3: Wool Carpet....... 14 Table A-5. Experiment No. 4: Nylon Carpet. . . . . 16 Table A-6. Experiment No. 5: Nylon Carpet (Floor Mount) 18

$\mathrm{V}$ 
. 


\section{James G. Quintiere and James W. Raines}

Five experiments were conducted using an ASTM E 84 tunnel test facility. These included a calibration test, three standard tests involving carpet materials, and one test in which a carpet material was tested on the floor of the duct. In addition to the measurements recorded during a standard test, instrumentation was added to measure inlet air velocity, temperature within the test section of the duct, and heat flux. From these measurements mass and energy balances were determined for each experiment. The results indicate that inlet air mass flow rate dropped during a test and appears to depend on the extent of burning in the duct. The energy balance results indicate that for the calibration run about half of the energy of the gas burner is lost by radiation and convection to the walls in the test section of the tunnel. During combustion of a test specimen, significant energy losses occur in the last 9 feet of the test section even after the flame tip has reached the exit of the tunnel.

Key words: ASTM E 84; carpets; energy balance; flame spread; mass balance; test method.

\section{INTRODUCTION}

Many building code and regulatory agencies set flammability acceptance requirements for interior surface lining material based on performance established by the ASTM E 84-70 [1] l tunnel test method. Essentially, the test consists of burning a material on the ceiling of a 25-foot duct under an initial air speed of $240 \mathrm{ft} / \mathrm{min}$ and an ignition exposure of $5,000 \mathrm{Btu} / \mathrm{min}$. Classification of a material is expressed in terms of a comparative rating system for the categories of flame spread, fuel contribution, and smoke production. The method originated at Underwriters" Laboratories and was first described by steiner in 1943 [2]. In 1950 it was approved by ASTM as a "Tentative Method."

\footnotetext{
${ }^{1}$ Numbers in brackets correspond with the literature references listed at the end of this paper.
} 
In recent years, a concern for carpet flammability has focused attention on the applicability of the "tunnel test" (ASTM E 84) in determining the flammability performance of floor coverings. In 1972, the National Building Code of Canada [3] adopted a modified version of ASTM E 84 for use in evaluating materials designed for floor application. Essentially, the modification consists of mounting the specimen on the floor of the tunnel and directing the ignition flame downward onto the material. Presumably, this change overcomes some problems associated with testing a flooring assembly mounted in a ceiling orientation. Another consideration, not restricted to flooring materials, concerns the variability of results from the tunnel test. Lee and Huggett [4] reported on an interlaboratory evaluation of the test method. They reported the variation in test performance within and among eleven laboratories. Other studies, by Endicott and Bowhay [5] and Groah [6], examined the effect on test performance of system variables.

In the present study, measurements of velocity and temperature were made during four tunnel tests. The sample materials were carpets. The purpose of the experiments was to assess the applicability of the tunnel test for measuring the flammability performance of floor covering materials. This subject has been discussed by Quintiere and Huggett [7], and it will not be pursued any further here. The present report deals with the results and analysis from these experiments which serve to characterize the thermal and flow conditions during a tunnel test.

\section{DESCRIPTION OF EXPERIMENTS}

The tunnel tests were conducted using the test facility [1] operated by the Hardwood Plywood Manufacturers Association in Arlington, Virginia. The instrumentation used in these experiments is shown in figure 1. An array of five pitot tubes was located in the plane of the rectangular orifice opening at the entrance of the tunnel. This arrangement would then provide a convenient means of determining total air inflow rate. Each pitot tube was connected to a pressure transducer which had been calibrated over a range of 0 to 0.1 inch of water. These calibrations showed a linear relationship between transducer voltage output and pressure difference. Arrays of thermocouples were positioned within the test section and at the end of the flame spread zone of the tunnel. At each station five thermocouples were arranged vertically 2 inches apart. Two thermocouples (Nos. 4 and 5) at section A-A (see fig. 1) attempted to measure the lateral variation in temperature; however, the support for these two thermocouples melted during the tests and these temperature data were disregarded. Bare chromel-alumel thermocouples were used. 
A radiometer (with a sapphire window) was located 16 feet from the ignition burner and was positioned on the floor of the tunnel to view the burning specimen.

Five tests were run. Each test was conducted in the standard manner prescribed by ASTM E 84-70 [1] with one exception. The exception was the last test conducted, which mounted and directed the igniting burners downward to impinge a flame onto the floor. A description of the experiments and test materials is given in table 1 . The same specimen materials were tested in experiments 4 and 5 to compare the standard ceiling-mounted results with a floor-mounted configuration.

All data were recorded on a digital data acquisition system over a time span for the standard test of 10 minutes duration. In experiment 1 , velocity data were not recorded, and the radiometer was not used in experiment 5. A complete scan of all data channels was made each 10 seconds during the test and the resulting data were processed by computer.

\section{RESULTS AND ANALYSIS}

The flammability classification results are given in table 2. The classification results are based on measurements and observations recorded during a standard ASTM E 84 tunnel test. The prescription for determining the classification indices is described in reference [1]. The flame-spread classification is derived from observations of the flame tip as burning progresses along the sample. These results are plotted in figure 2. The "fuel factor" is based on the temperature-time curve of a thermocouple located at the exit end of the test chamber and 1 inch below the test specimen. These temperature curves are shown in figure 3. The smoke density factor given in table 2 is derived from the integral of light attenuation by the combustion products over the 10 minute duration of the test. All three of these classification indices can, in theory, be related to more quantitative flammability parameters such as rate or extent of flame spread, rate of energy release, and rate of smoke or particulate production. However, the interpretation and application of such quantitative parameters derived from the tunnel test remain to be specified.

The measurements taken beyond the standard test data are tabulated in appendix A. These data were analyzed to estimate the mass rate of air supply and the overall energy transfer rates in the tunnel. 


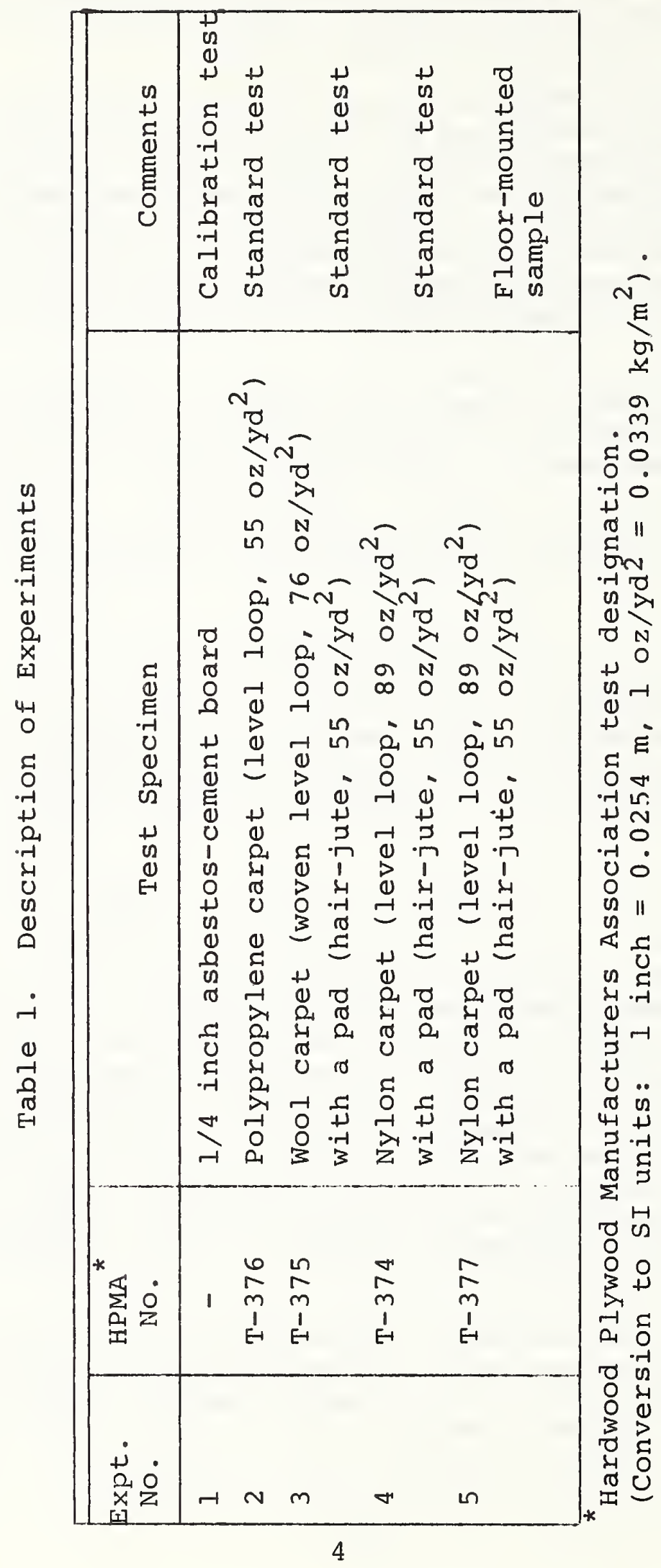


Table 2. Classification Results

\begin{tabular}{|c|c|c|c|}
\hline Test & $\begin{array}{c}\text { Flame-spread } \\
\text { Classification }\end{array}$ & $\begin{array}{c}\text { Fuel Contri- } \\
\text { buted Factor }\end{array}$ & $\begin{array}{c}\text { Smoke Density } \\
\text { Factor }\end{array}$ \\
\hline $\begin{array}{c}\text { Polypropylene } \\
\text { carpet; T-376 }\end{array}$ & 69 & 20 & 110 \\
$\begin{array}{l}\text { Wool carpet; } \\
\text { T-375 } \\
\begin{array}{c}\text { Nylon carpet; } \\
\text { T-374 }\end{array}\end{array}$ & 197 & 84 & 297 \\
$\begin{array}{c}\text { Nylon carpet, floor } \\
\text { mounted; T-377 }\end{array}$ & 169 & 69 & 243 \\
\hline
\end{tabular}

\subsection{Mass Flow Rate of Air}

The velocity data taken at the slit was used, in part, to determine the mass flow rate of air supplied to the tunnel test section. The mass flow rate was calculated by using

$$
\dot{\mathrm{m}}_{\mathrm{a}}=\int \rho \mathrm{VdA}
$$

which is approximated by

$$
\dot{m}_{a}=\rho_{a} \sum_{i=1}^{s} v_{i} A_{i}
$$

The velocity is assumed to be uniform over each of three equal area segments, $A_{i}(31 / 8 " \times 6 ")$. Channel 16 was disregarded, and channels 14 and 18 were averaged for one area segment. The result of these approximations yields

$$
\dot{\mathrm{m}}_{\mathrm{a}}=0.130 \mathrm{P}_{\mathrm{a}}\left(\mathrm{v}_{15}+\frac{\mathrm{v}_{14}+\mathrm{v}_{18}}{2}+\mathrm{v}_{17}\right) \frac{1 \mathrm{~b}_{\mathrm{m}}}{\mathrm{min}}
$$

where $\rho_{a}=0.07461 \mathrm{~b}_{\mathrm{m}} / \mathrm{ft} \mathrm{t}^{3}$

and $\quad V=$ velocity at the indicated channel location (ft/min). 
The results for the four test runs are shown in figures $4 \mathrm{a}-\mathrm{d}$. It should be pointed out that the initial tunnel flow rate, corresponding to test section conditions of $240 \mathrm{ft} / \mathrm{min}$ and $21^{\circ} \mathrm{C}$, is $25.4 \mathrm{lb} / \mathrm{min}$. Note that in each test the air velocity decreased over most or all of the tests and that this decrease ranged from about 19 to more than $28 \%$.

\subsection{Energy Balance}

By using the temperature profile data at the 15 and 24 foot stations in the test section along with the measured air supply rate, several energy balances can be made to estimate the magnitude of the energy flows in the tunnel. An energy balance applied to a control volume encompasing the test section space, bounded by the walls of the duct and stations 1 and 2, where station 2 is downstream of 1 , is given approximately as

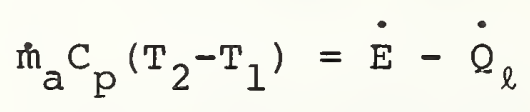

where $T_{1,2}$ is an effective temperature,

$\mathrm{E}$ is the energy release rate due to combustion, and

$\dot{Q}_{\ell} \quad$ is the conductive wall heat loss rate and radiative loss rate.

The mass of gas from the burners and the pyrolysis mass flow from the burning sample are small compared to the air supply and were neglected in the energy balance. The gas burner fuel contribution is about $5,000 \mathrm{Btu} / \mathrm{min}$ based on a design specification of the test method. Actually, for these experiments the gas flow rate to the burner indicated an average of $4,750 \mathrm{Btu} / \mathrm{min}$ based on a lower heating (net) value and $5,280 \mathrm{Btu} / \mathrm{min}$ based on a higher heating (gross) value. The 5,000 value was used in the subsequent calculations, although it is probably more correct to use $4,750 \mathrm{Btu} / \mathrm{min}$. An average value of $\mathrm{C}_{\mathrm{p}}$ was taken to be $0.202 \mathrm{Btu} / 1 \mathrm{~b}^{\circ} \mathrm{R}$ which corresponds to nitrogen at $427^{\circ} \mathrm{C}$. An effective temperature was determined by an area-weighted average. For example, at station B

$$
\mathrm{T}_{B}=\frac{\mathrm{T}_{10}+\mathrm{T}_{11}+\mathrm{T}_{12}}{6}+\frac{\mathrm{T}_{9}+\mathrm{T}_{13}}{4}
$$

This would correspond to a bulk temperature, provided the mass velocity $(\rho V)$ is equal over the duct cross section. It would 
overestimate the bulk temperature if velocity (V) were equal over the cross section. The results of several energy balances will be given.

Figures 5 and 6 show the convective enthalpy flow rates at stations $A$ and $B$, respectively, for the calibration test. In both cases ( $A$ and $B$ ) the energy loss rate is given by

$$
\dot{Q}_{i}=5,000 \frac{B t u}{m i n}-\dot{m}_{a} c_{p}\left(T_{i}-T_{\infty}\right), i=A, B
$$

where a constant $\mathrm{m}_{\mathrm{a}}=25.4 \mathrm{lb} / \mathrm{min}$ was used. It is seen that for a 5,000 Btu/min burner energy release rate, more than 2,000 $\mathrm{Btu} / \mathrm{min}$ is lost before station $\mathrm{A}$, and an additional $600 \mathrm{Btu} / \mathrm{min}$ loss is incurred between stations $A$ and $B$.

Figures 7 a through $7 d$ display the net energy loss rate for a control volume bounded by sections $A$ and $B$. The net energy loss rate is the difference $\dot{Q}_{\ell}-\dot{E}$ and was determined by

$$
\dot{Q}_{\ell}-\dot{E}=\dot{m}_{a} c_{p}\left(T_{A}-T_{B}\right)
$$

In Figure 7a, the calibration run, no energy release takes place between $A$ and $B$; hence, only the loss associated with the burner is displayed. In figures $7 \mathrm{~b}$ and $7 \mathrm{c}$ it is interesting to notice that a net energy production rate is not established between $A$ and $B$ until well after the specimen flame has reached the end of the duct.

\section{CONCLUSIONS}

Velocity measurements and calculations have shown a drop in air supply rate during burn in the ASTM E 84 tunnel test. The drop in air flow was at least 19 percent in all of the cases tested. It is not known if this drop in flow is associated with a temperature rise in the duct [7], mass transfer by the specimen, or whether it is peculiar to a particular tunnel facility. Moreover, it is not known what effect this reduction in oxygen supply has on tunnel flame spread and smoke measurements.

The energy balance calculations give some insight to the magnitude of energy flows in the tunnel. There appears to be a substantial loss of energy near the burner flame. Also, the energy losses appear to be significant during burning, at least during the time period in which the flame has not yet reached the end of the duct. 


\section{REFERENCES}

[1] Standard Test Method for Surface Burning Characteristics of Building Materials, ASTM E 84-70, American Society of Testing and Materials, Philadelphia, Pennsylvania, 1970.

[2] Steiner, A. J., Method of Fire-Hazard Classification of Building Materials, ASTM Bulletin, 19-22 (Mar. 1943).

[3] Standard Method of Test for Surface Burning Characteristics of Flooring and Floor Covering Materials, CSA B 54.9-1972, Canadian Standards Association (1972).

[4] Lee, T. G. and Huggett, C., Interlaboratory Evaluation of the Tunnel Test (ASTM E 84) Applied to Floor Coverings, Nat. Bur. Stand. (U.S.), NBSIR 73-125 (Mar. 1973).

[5] Endicott, L. E. and Bowhay, R. B., A Statistical Evaluation of the Fire Hazard Classification Furnace (ASTM E 84-68), Materials Research and Standards, American Society of Testing and Materials, Philadelphia, Pennsylvania, 19-21, 50,52 (May 1970).

[6] Groah, W. J., A Study of Certain Operating and Material Variables of the 25-Foot Tunnel Flamespread Test, Forest products Journal, Vol. 23, No. 12, 39-45 (Dec. 1973).

[7] Quintiere, J. and Huggett, C., An Evaluation of Flame Spread Test Methods for Floor Covering Materials, Fire Safety Research, Proceedings of a Symposium on Fire held at the National Bureau of Standards on August 22, 1973, Nat. Bur. Stand. (U.S.), Special Publication SP-4ll (Nov. 1974). 
The temperature, velocity, and heat flux data are tabulated for each experiment. Table A-l lists the data channel numbers and corresponding sensors as indicated in figure 1. Tables A-2 through A-6 list the data taken for each experiment. In some cases data were faulty or changes were made in sensor location. In all the experiments channel 16 yielded erroneous velocity data due to an improper installation. Channel 14 in experiment 2 appeared, initially, to give an erroneously high output. In experiments 1 through 4 , the thermocouples on channels 4 and 5 may not have remained in position and these data should be regarded with caution. In experiment 5 , thermocouples 4 and 5 were relocated to measure temperature near the ceiling and at the carpet surface, respectively. Also, in experiment 5 some thermocouples apparently did not function properly, and the heat fluxmeter was not used. Finally, it should be noted that velocity and heat flux measurements were not taken in experiment 1 . 


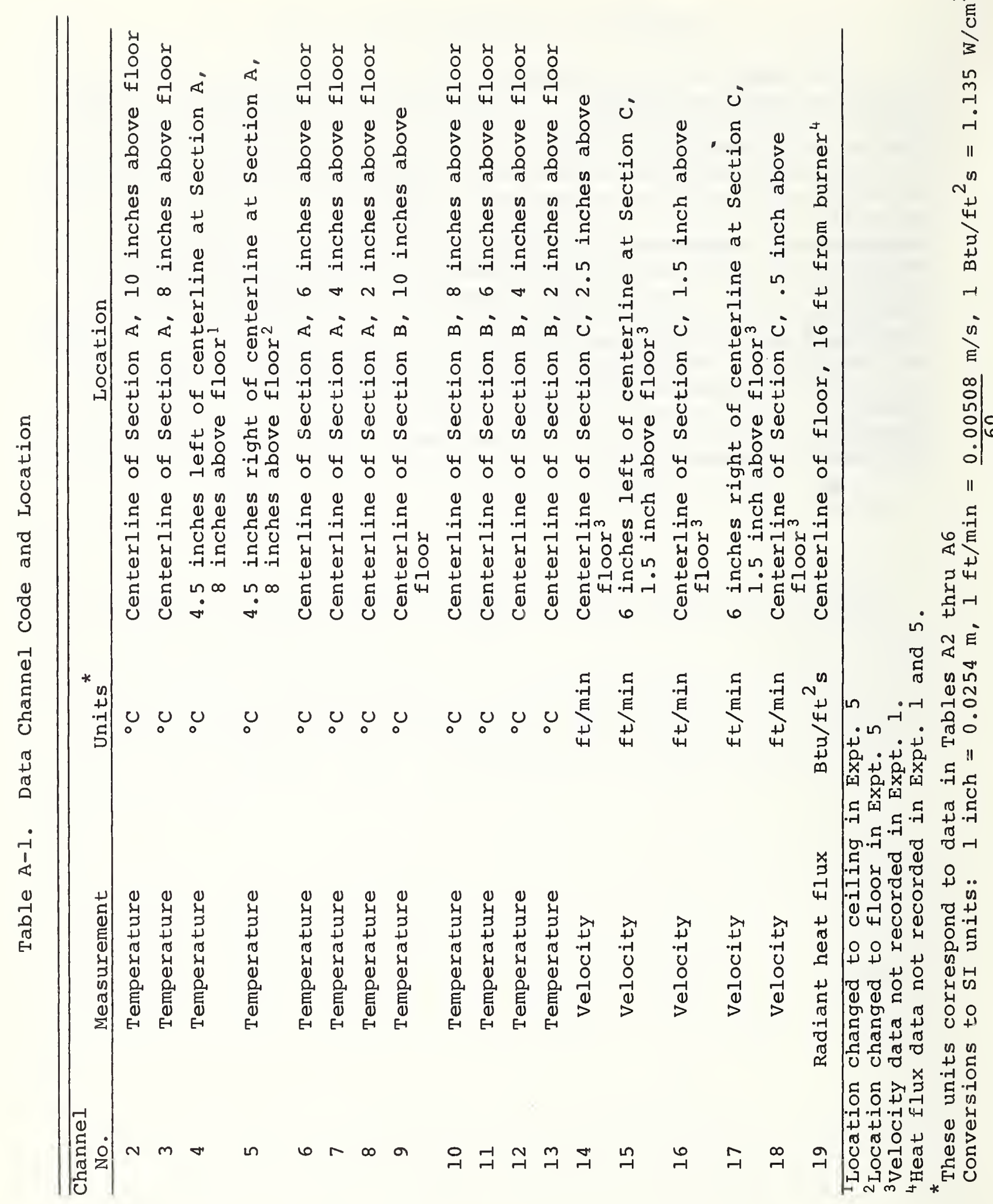




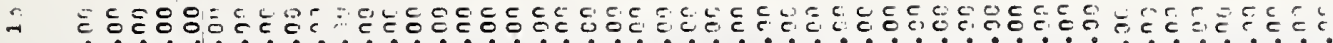

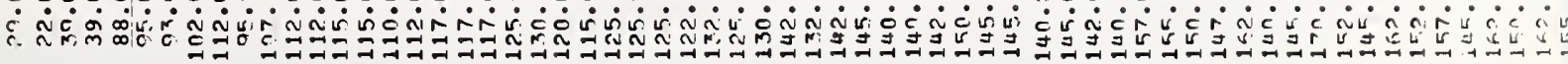

a $\quad$ ᄃ

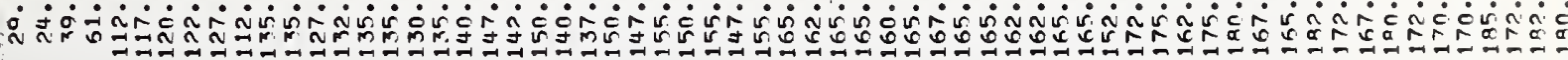

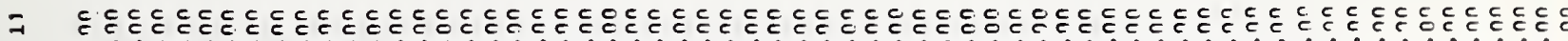

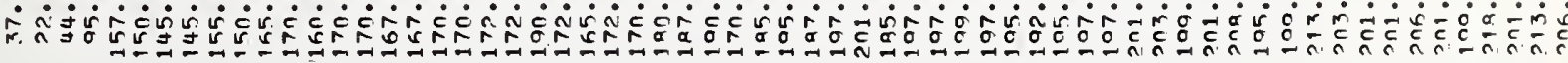

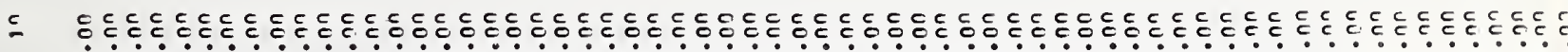

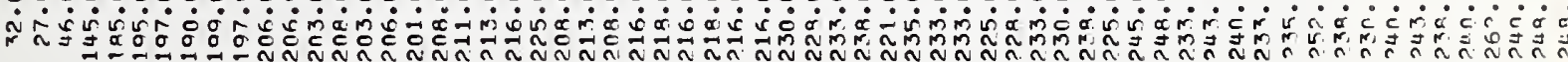

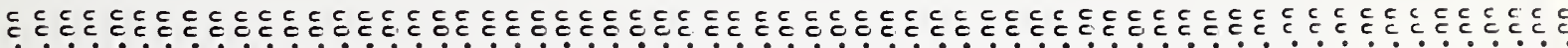

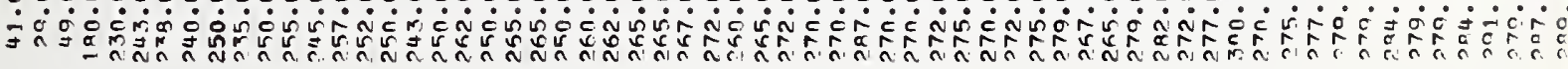

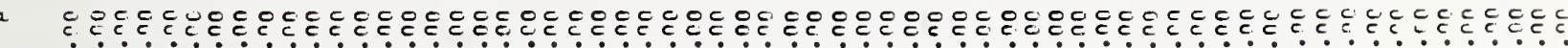

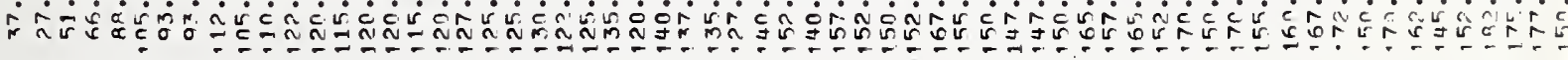

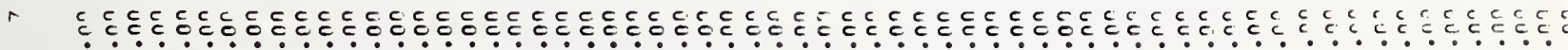
rój

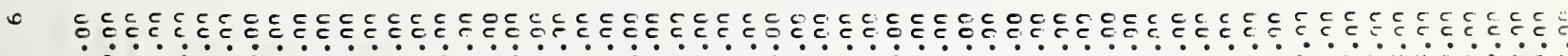

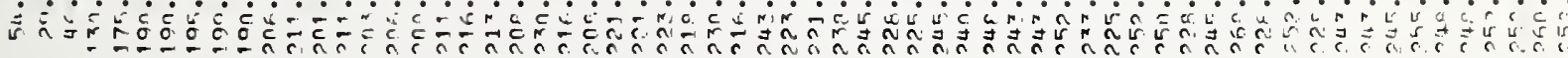

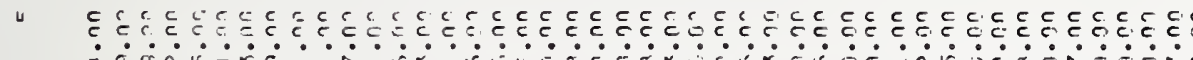

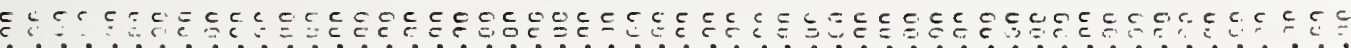

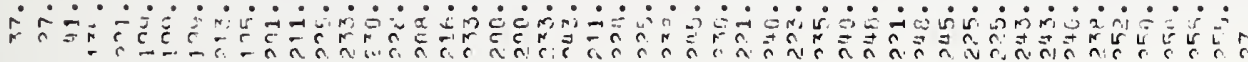

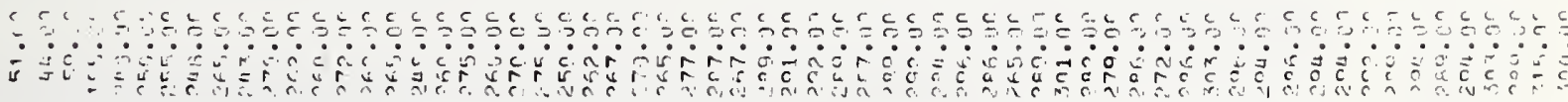

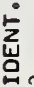

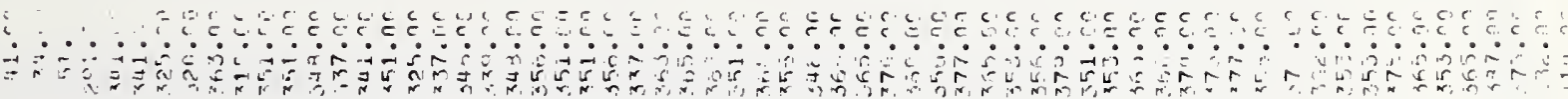

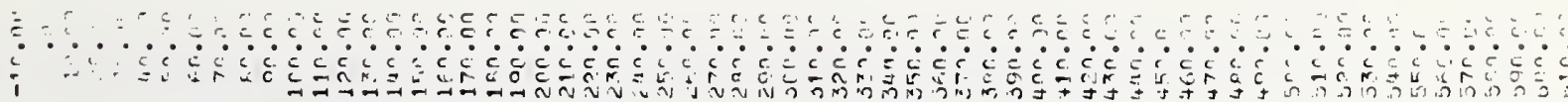

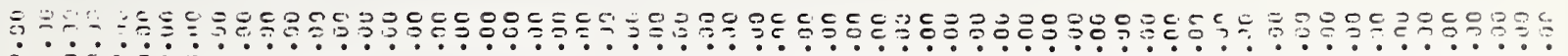
i 


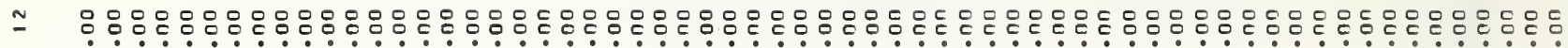

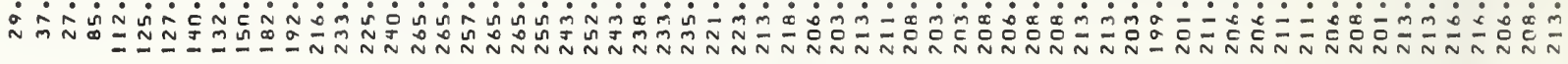

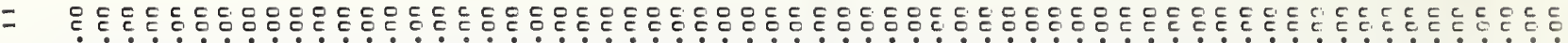

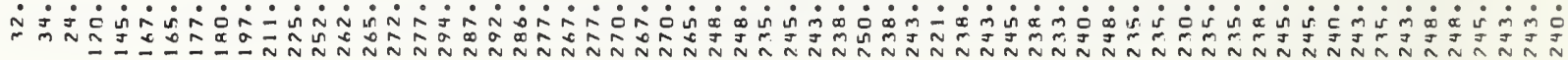

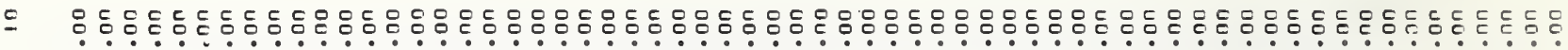

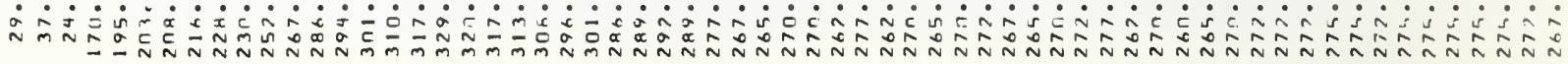

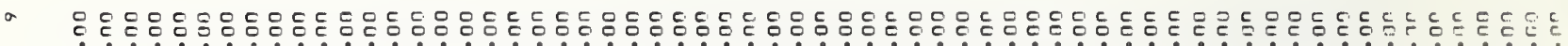

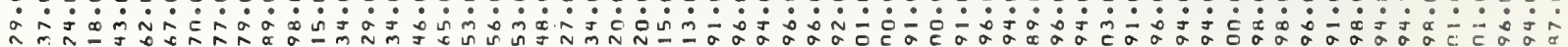

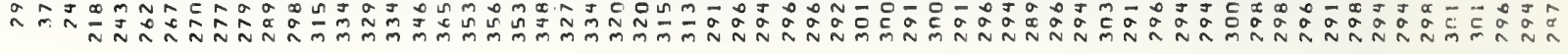

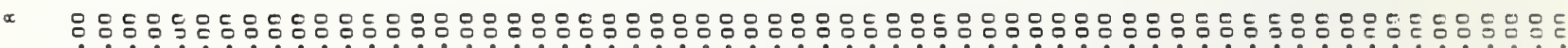

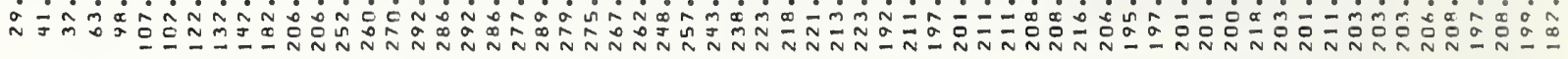

-

Ł

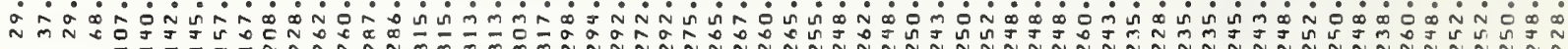

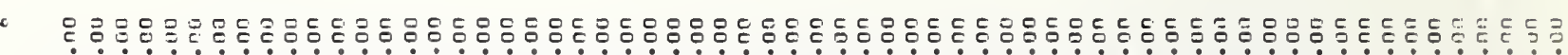

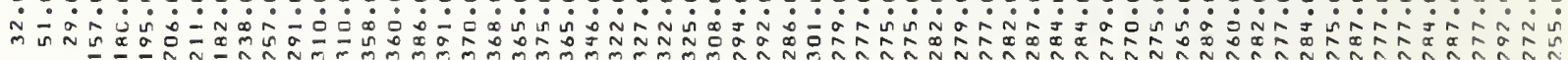

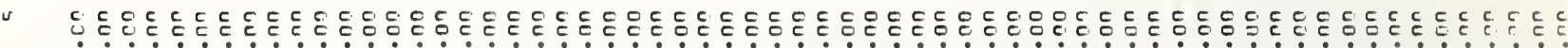

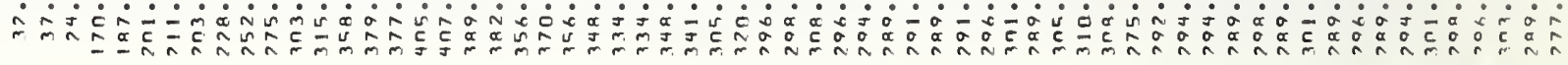

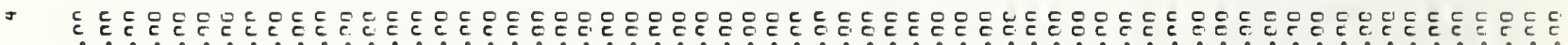

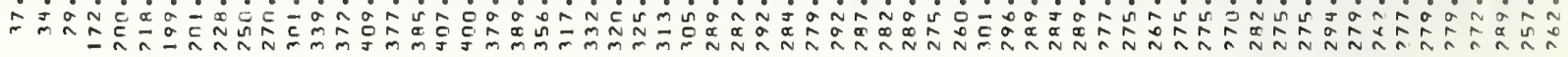

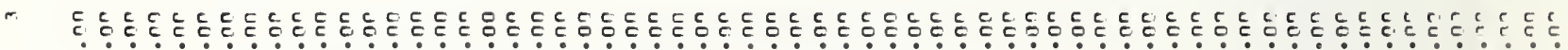

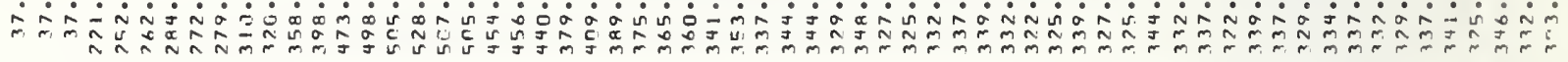

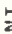

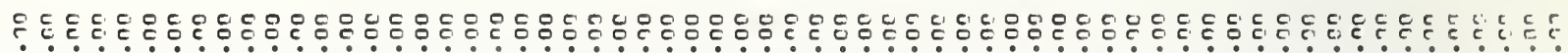

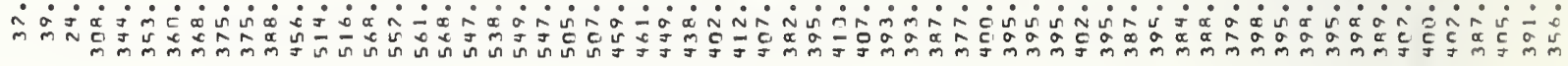

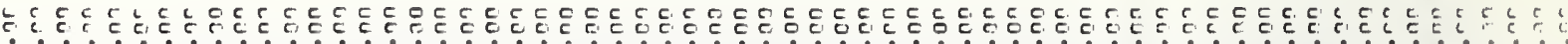

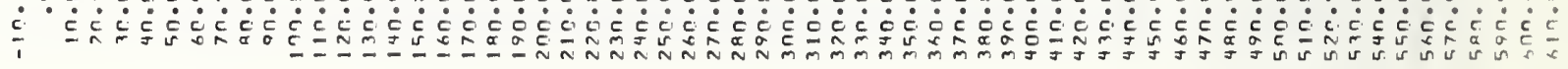

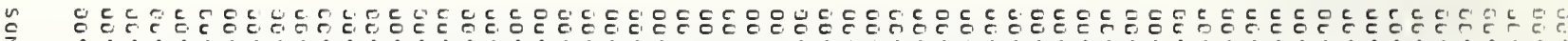

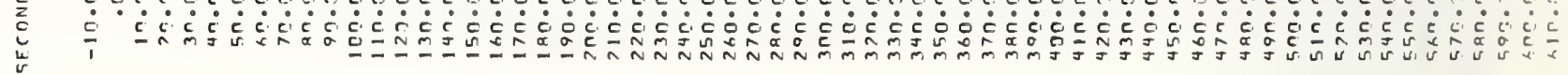


-

× -

$=$ ᄃ -

-

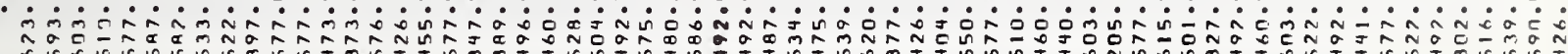

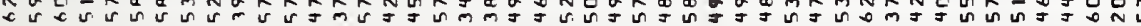

บ -

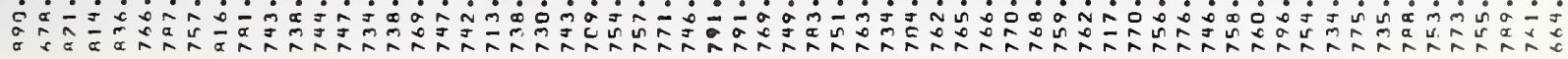

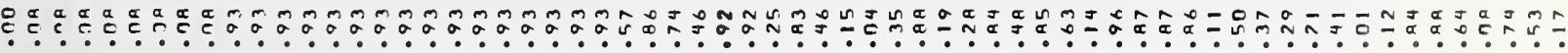

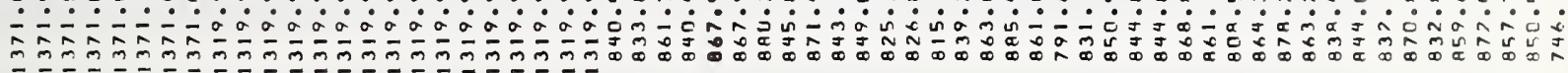

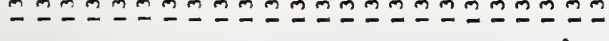

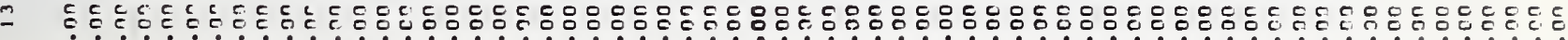

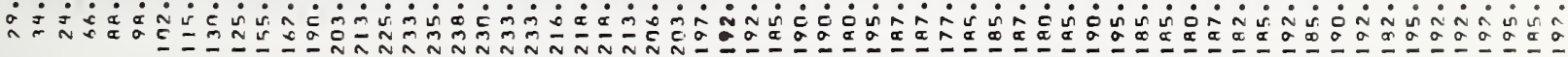

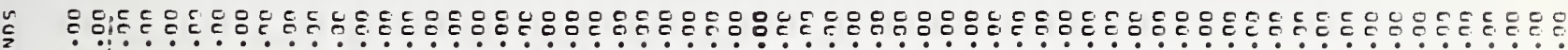

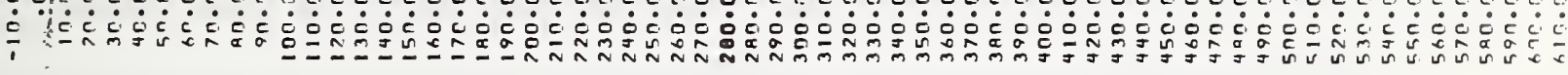




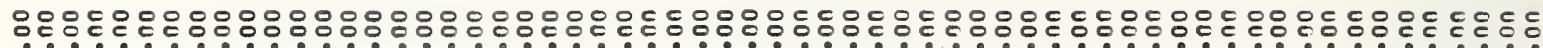

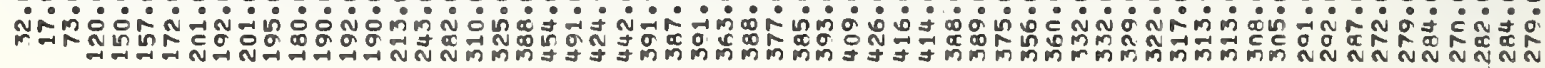

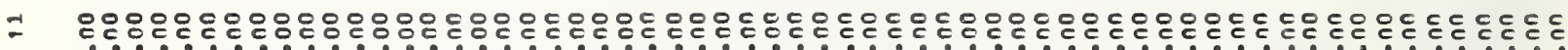

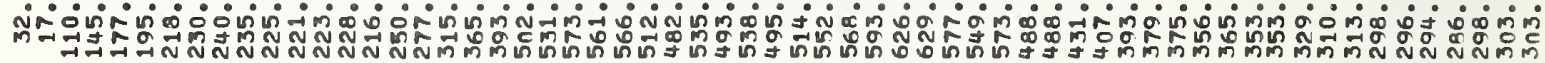

ㄱ

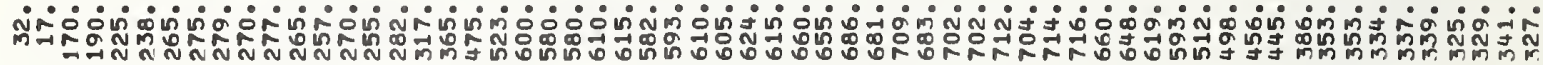

ผ

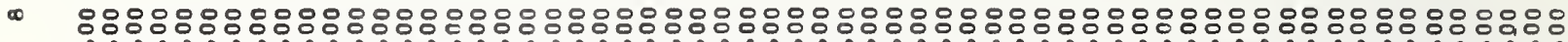

Nं

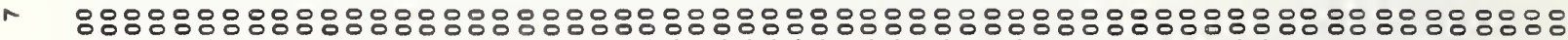
N่mน mN้

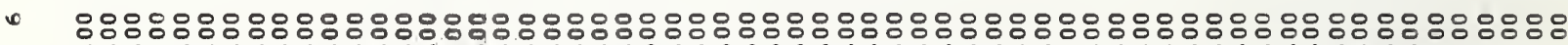

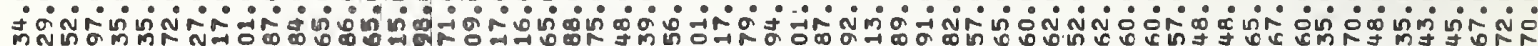

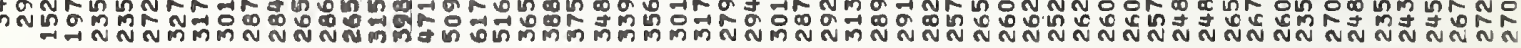

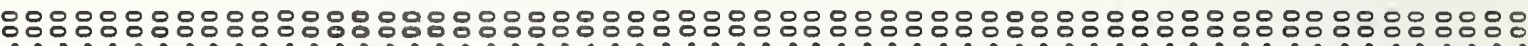

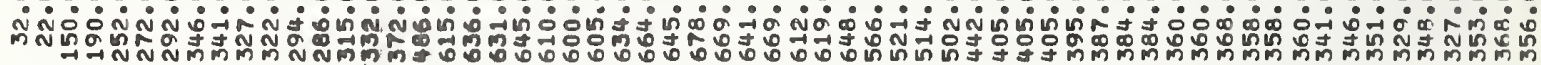

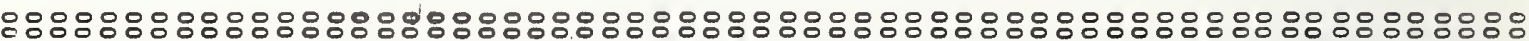

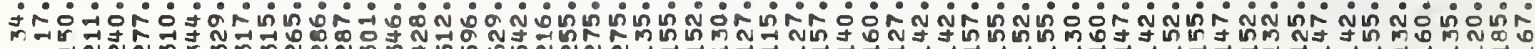

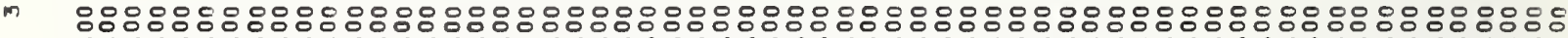

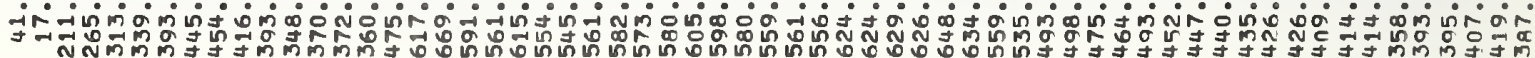

点

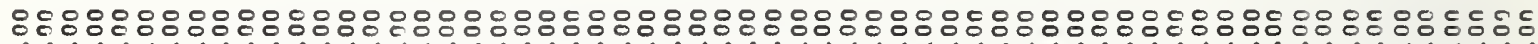
Niñ

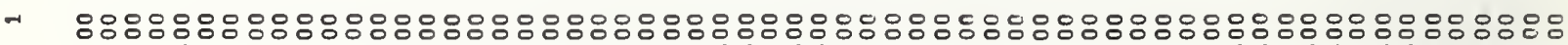

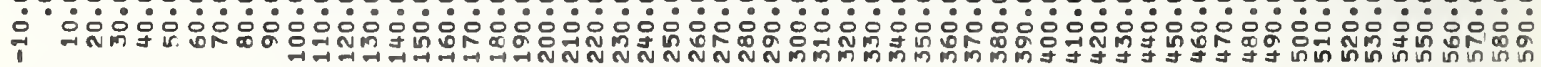

ఋ

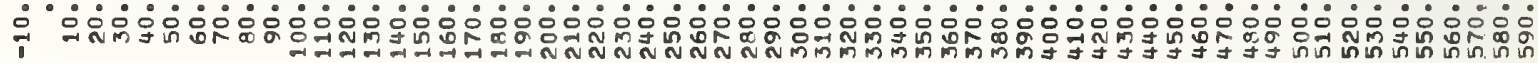




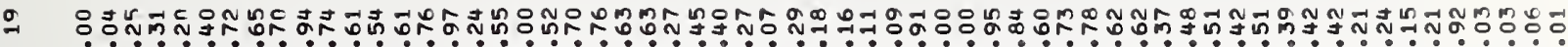
-

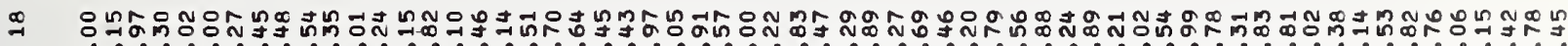

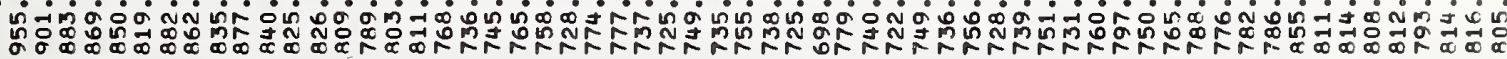

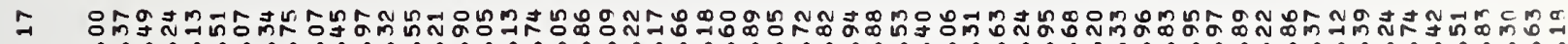

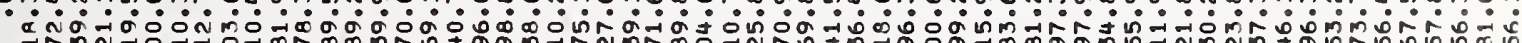

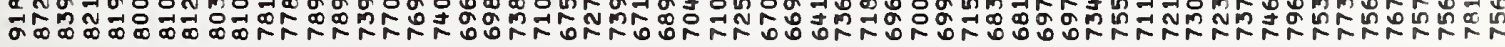

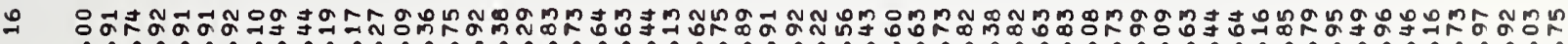

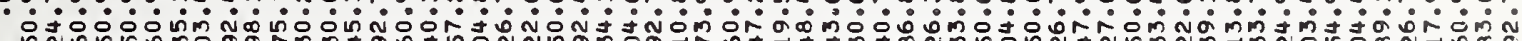

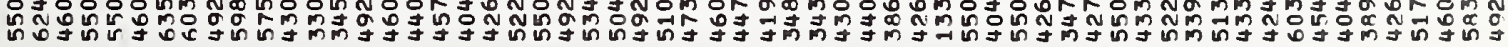

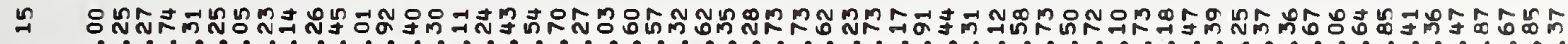

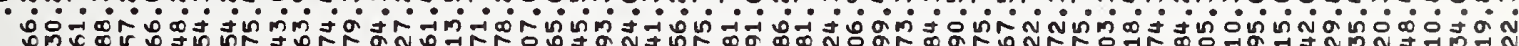

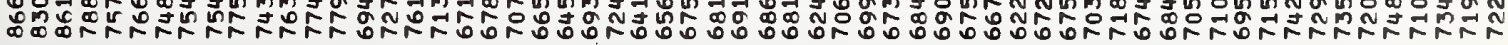

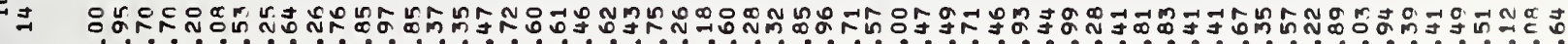

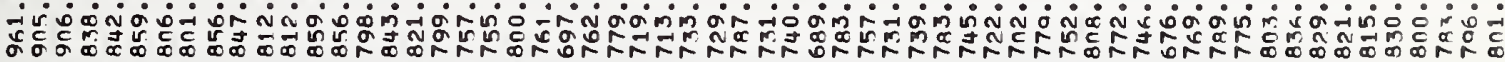

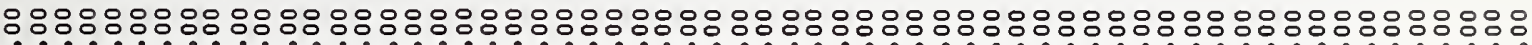

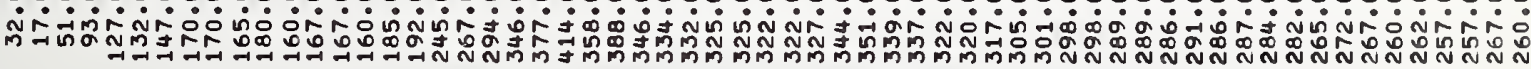

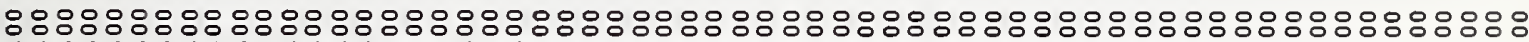

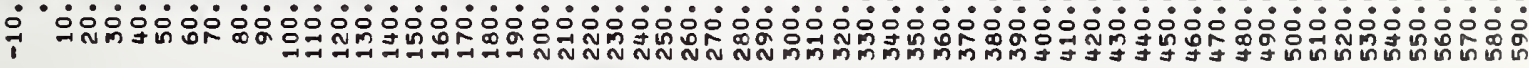




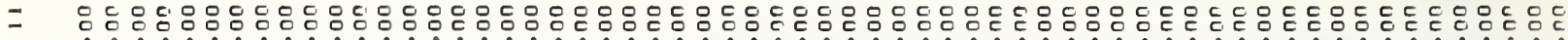

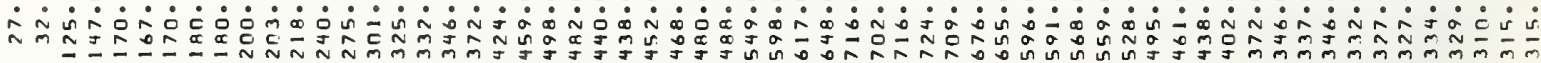

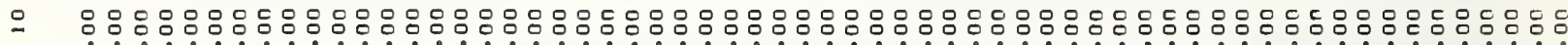

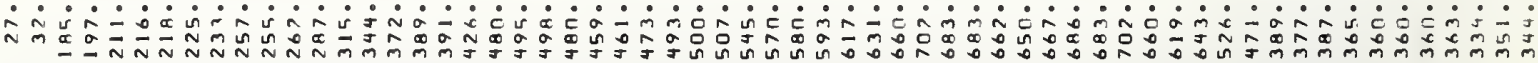

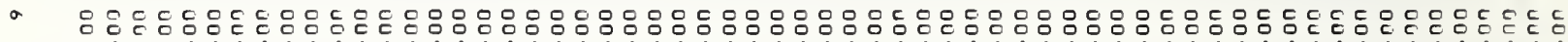

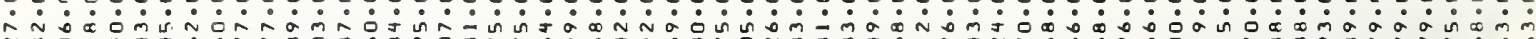
$\hat{N} \tilde{N}$

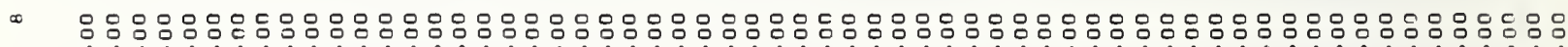

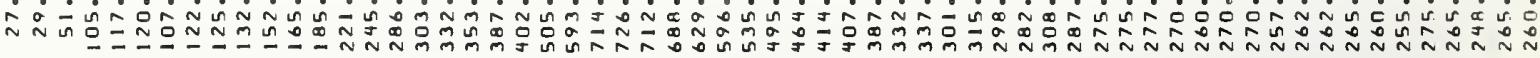

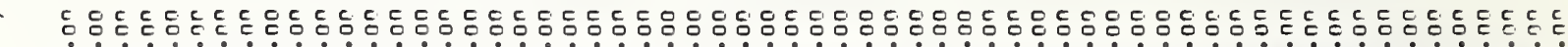

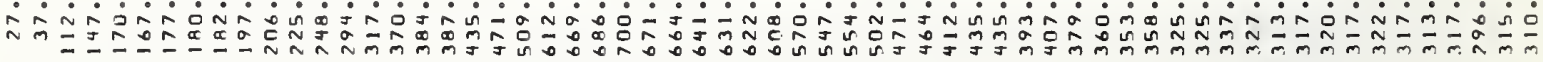

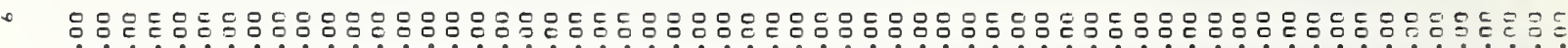

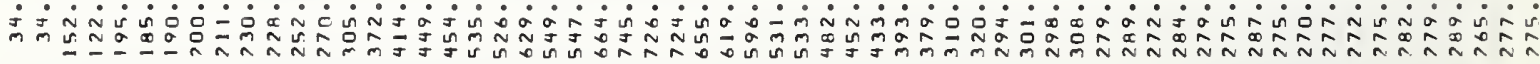

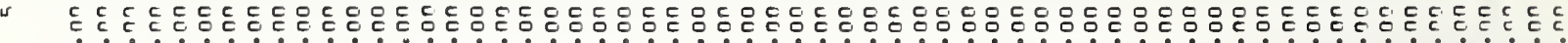

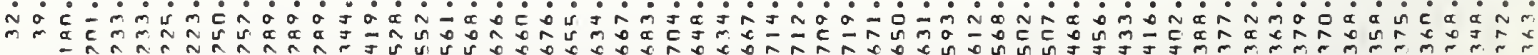

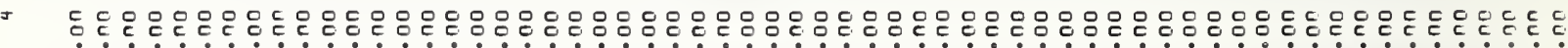

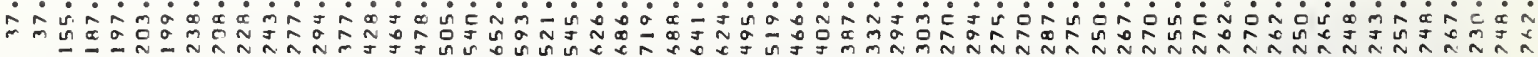

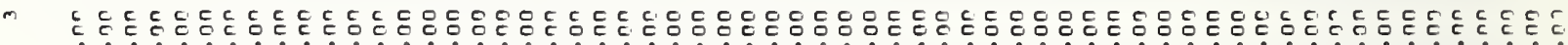

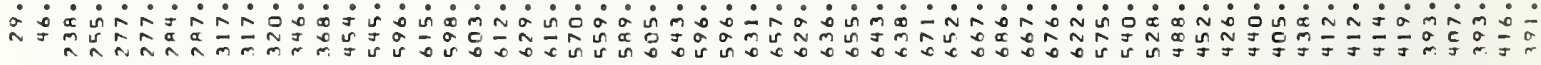

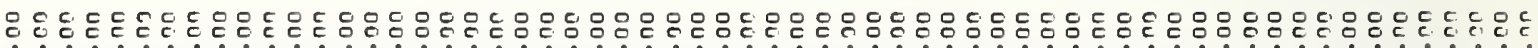

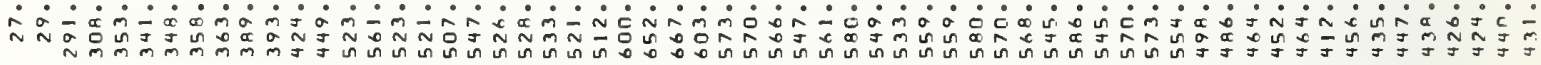

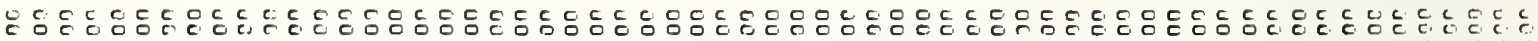

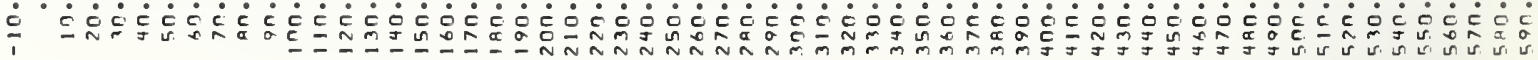

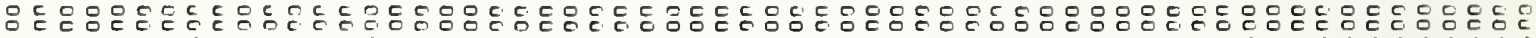
定 


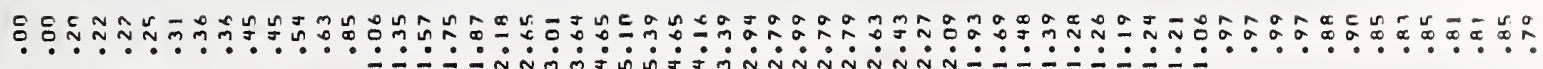

× $\quad \bar{c}$

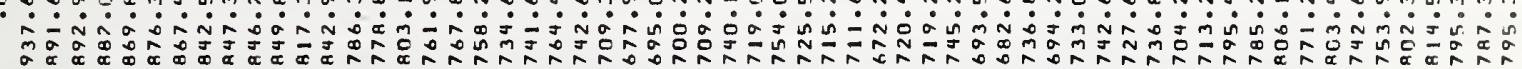

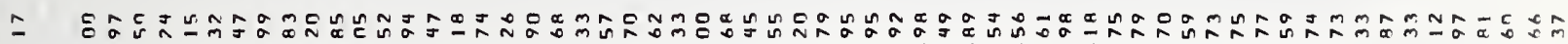

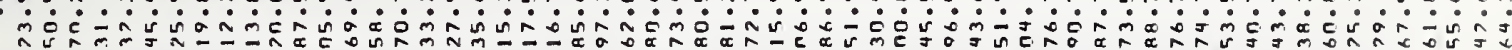

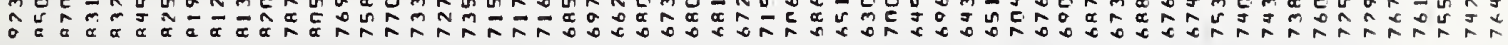

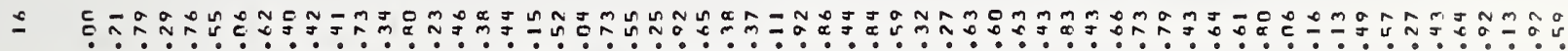

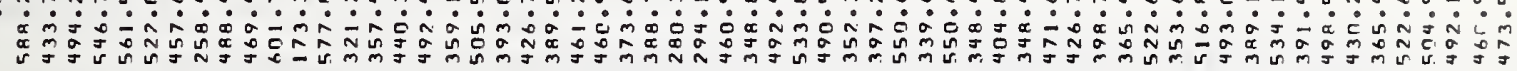

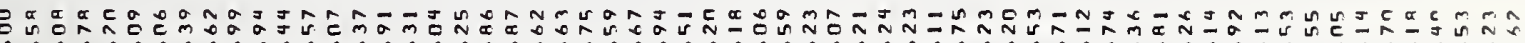

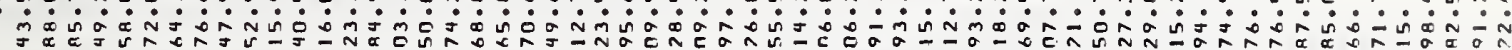

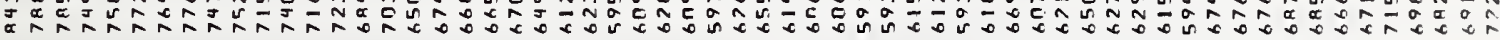

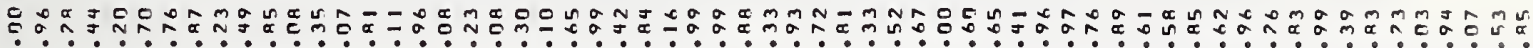

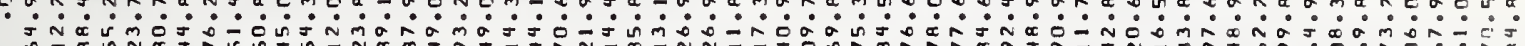

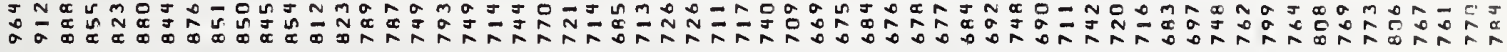

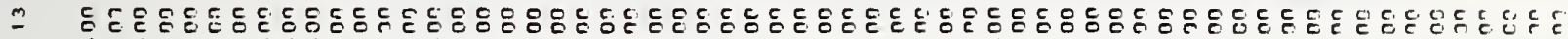

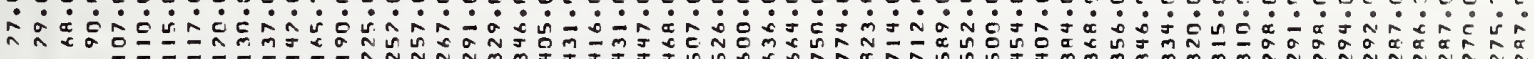

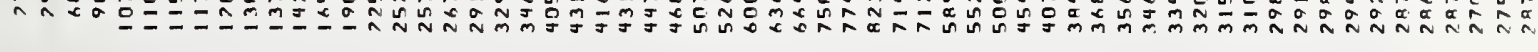

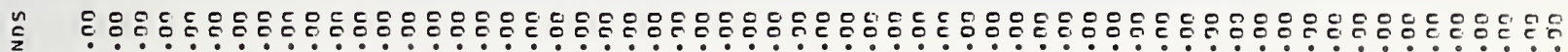

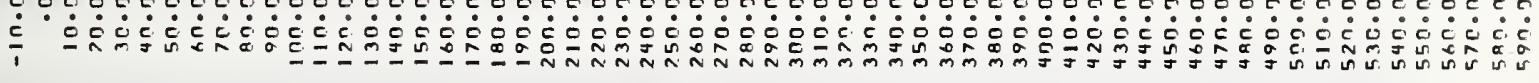




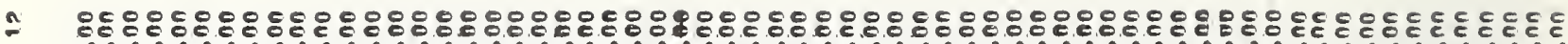

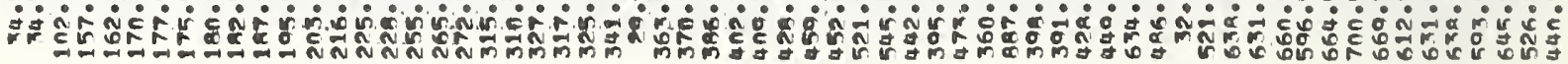

= मिं

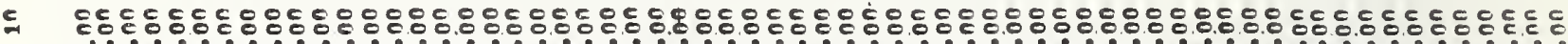

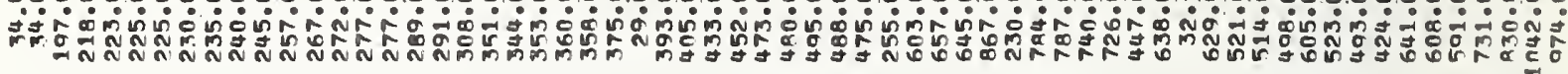

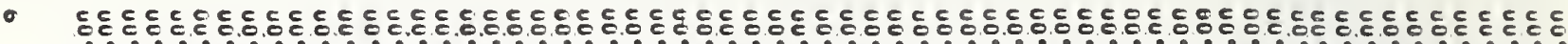

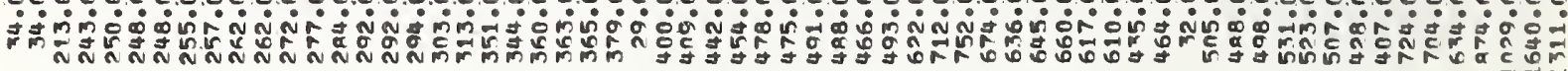

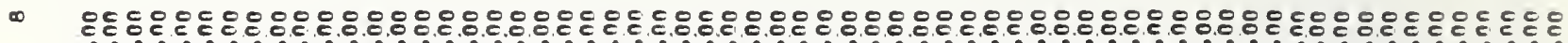

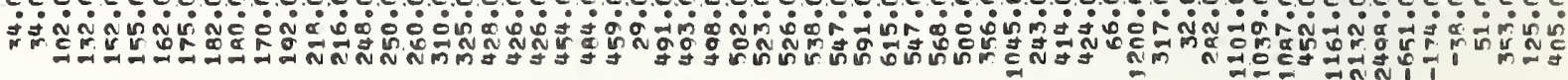

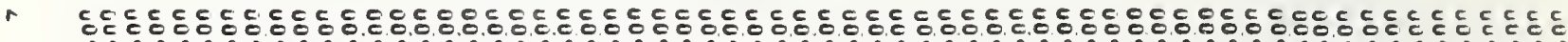

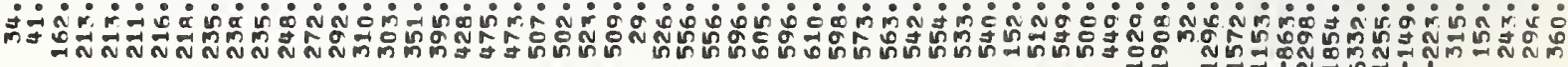

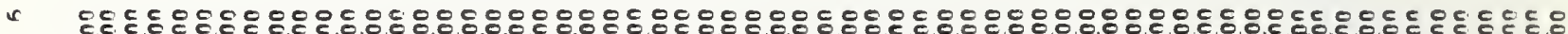

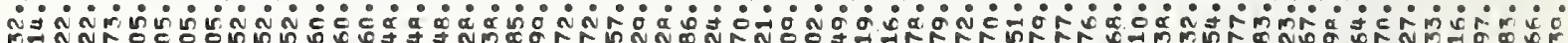

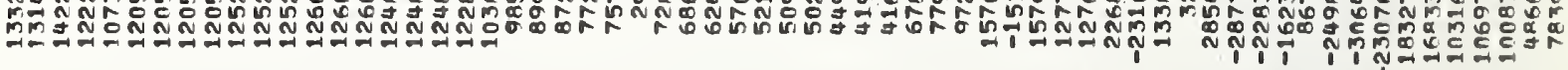

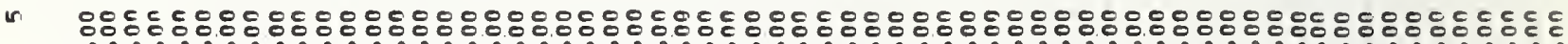

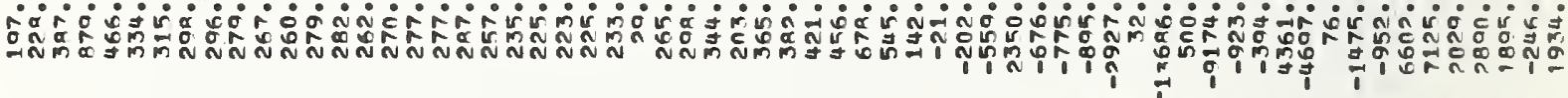

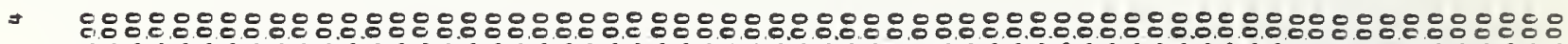

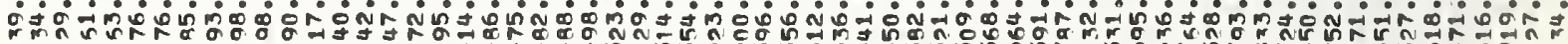

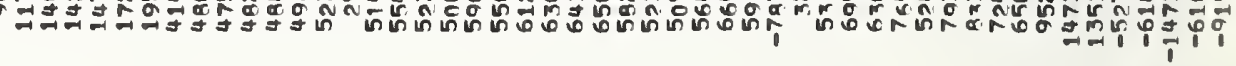

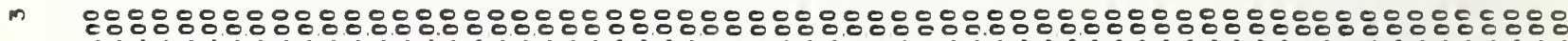

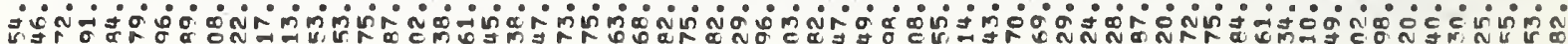

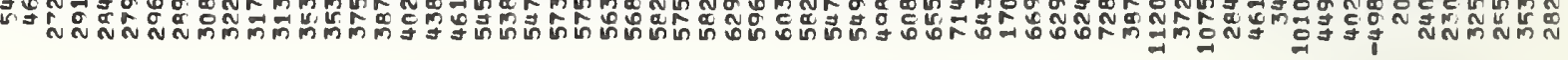

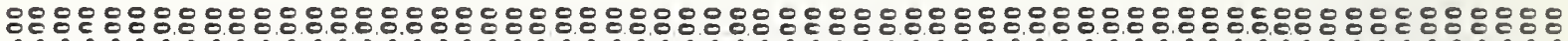

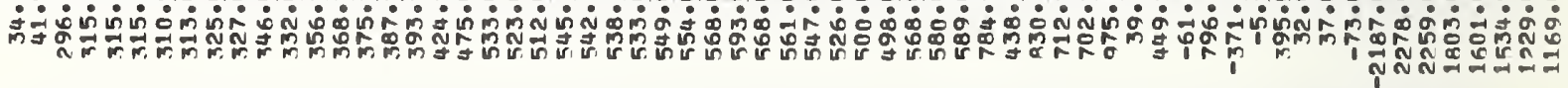

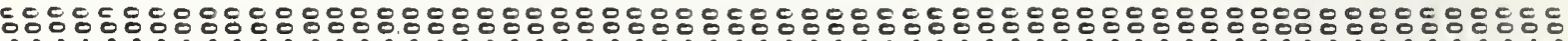

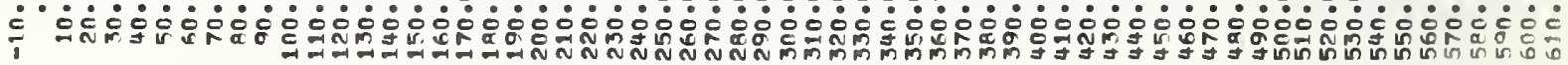

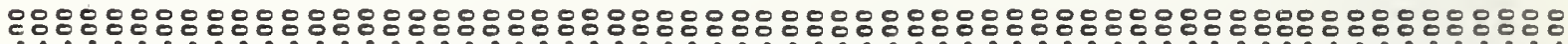

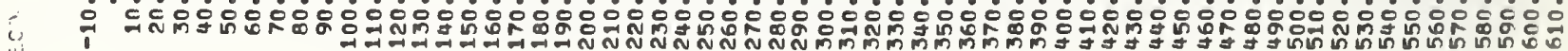




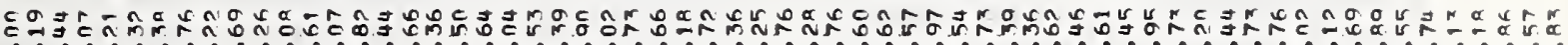

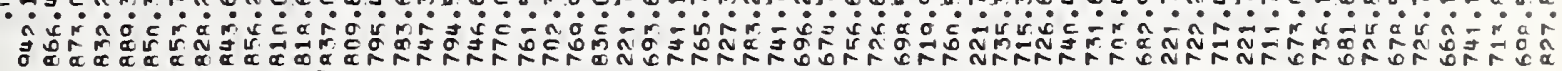

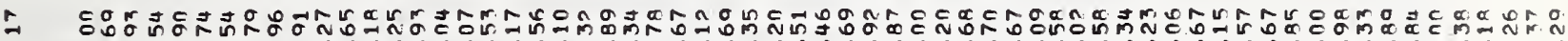

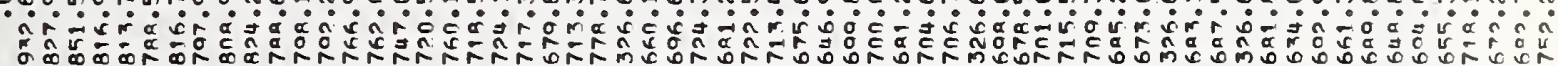

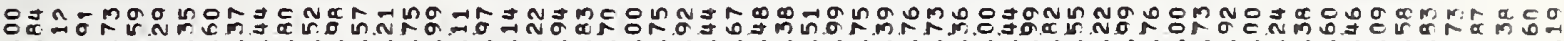

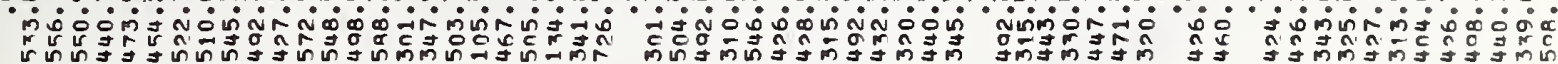

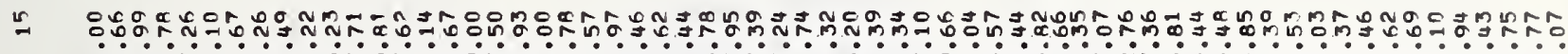

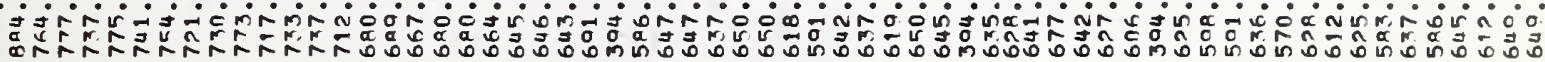

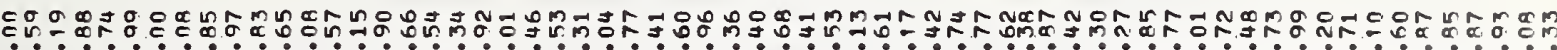

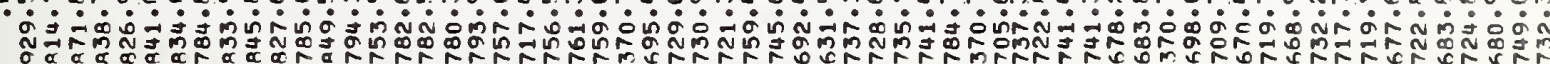

-

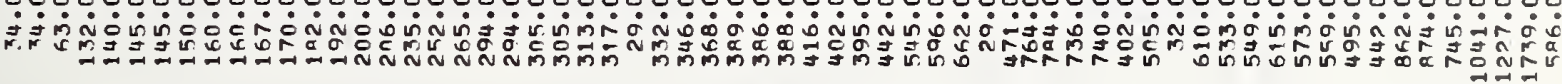

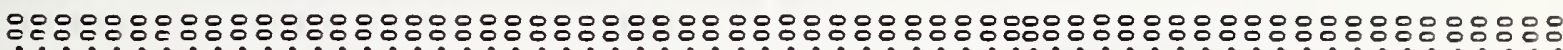

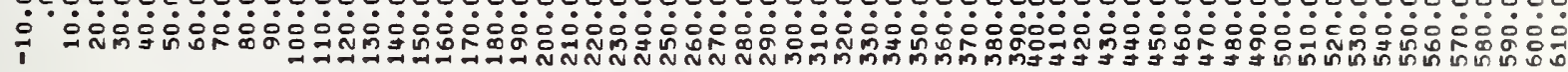




\section{APPENDIX B. SI CONVERSION UNITS}

In view of present accepted practice in this technological area, U.S. customary units of measurement have been used throughout this report. It should be noted that the U.S. is a signatory to the General Conference on Weights and Measures which gave official status to the metric SI system of SI units in 1960. Readers interested in making use of the coherent system of SI units will find conversion factors in ASTM Standard Metric Practice Guide, ASTM Designation E 380-72 (available from American Society for Testing and Materials, 1916 Race street, Philadelphia, Pennsylvania 19103). Conversion factors for units used in this paper are:

Length

$$
\begin{aligned}
& 1 \text { in }=0.0254^{*} \text { meter } \\
& 1 \text { ft }=0.3048^{*} \text { meter }
\end{aligned}
$$

Area

1 in $^{2}=6.4516^{*} \times 10^{-4}$ meter $^{2}$

$1 \mathrm{ft}^{2}=9.2903 \times 10^{-2}$ meter $^{2}$

Mass

$11 \mathrm{~b}=0.454 \mathrm{~kg}$

Pressure

1 in of $\mathrm{H}_{2} \mathrm{O}=248.8 \mathrm{~Pa}$

Energy

$1 \mathrm{Btu}=1054 \mathrm{~J}$

Temperature

${ }^{\circ} \mathrm{C}=5 / 9$ (Temperature $\left.{ }^{\circ} \mathrm{F}-32\right)$

Power

$1 \mathrm{Btu} / \mathrm{min}=17.57 \mathrm{~W}$

Exact Value 


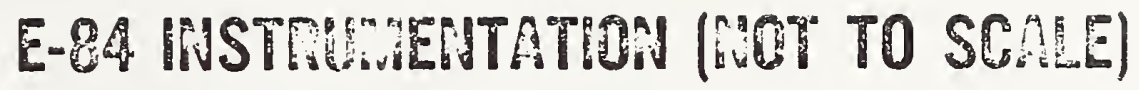

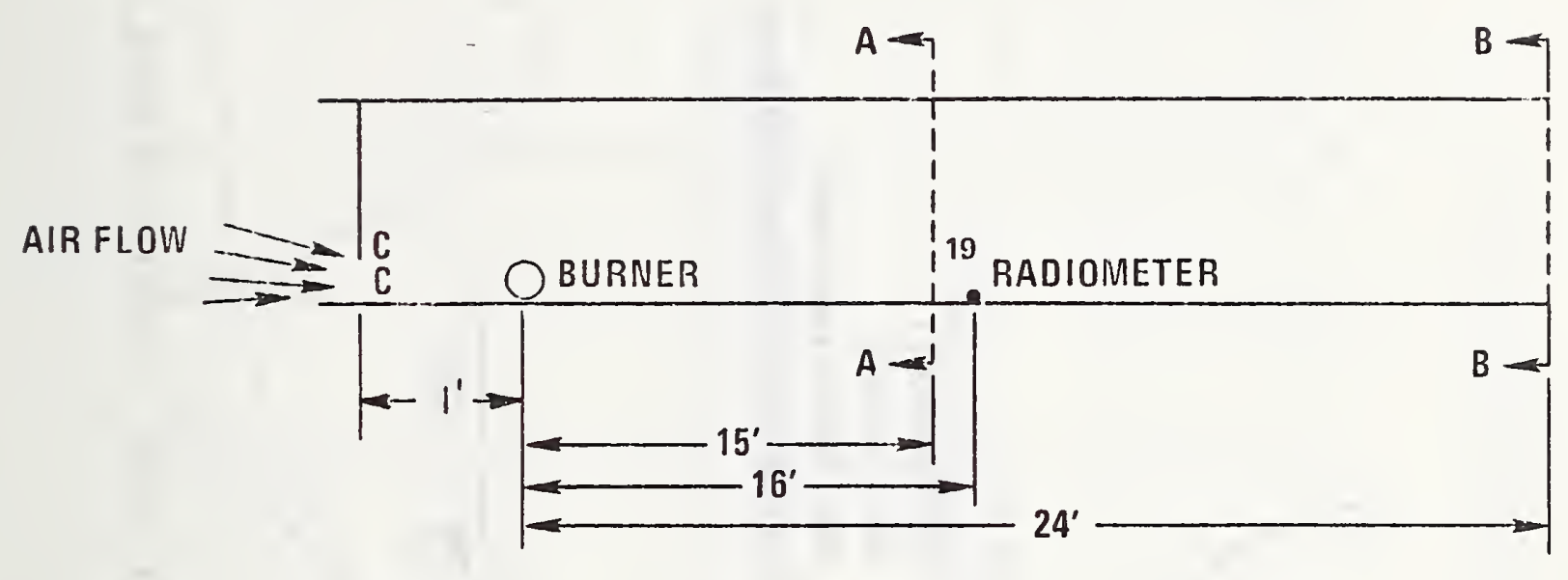

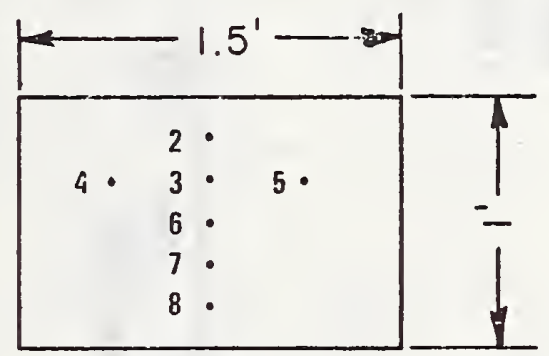

SECTION A-A

TC LOCATIONS @ 15'

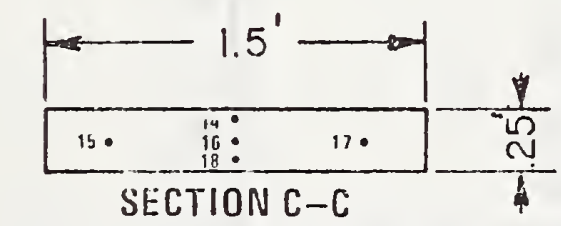

PITOT TUBE LOCATIONS @ AIR INTAKE
THERMOCOUPLES PITOT TUEES

RADIOMETER
$2-13$

$14-18$

19

Figure 1. Schematic of instrumentation. ( 1 in $=0.0254 \mathrm{~m}$, l ft $=0.3048 \mathrm{~m}$ ). 


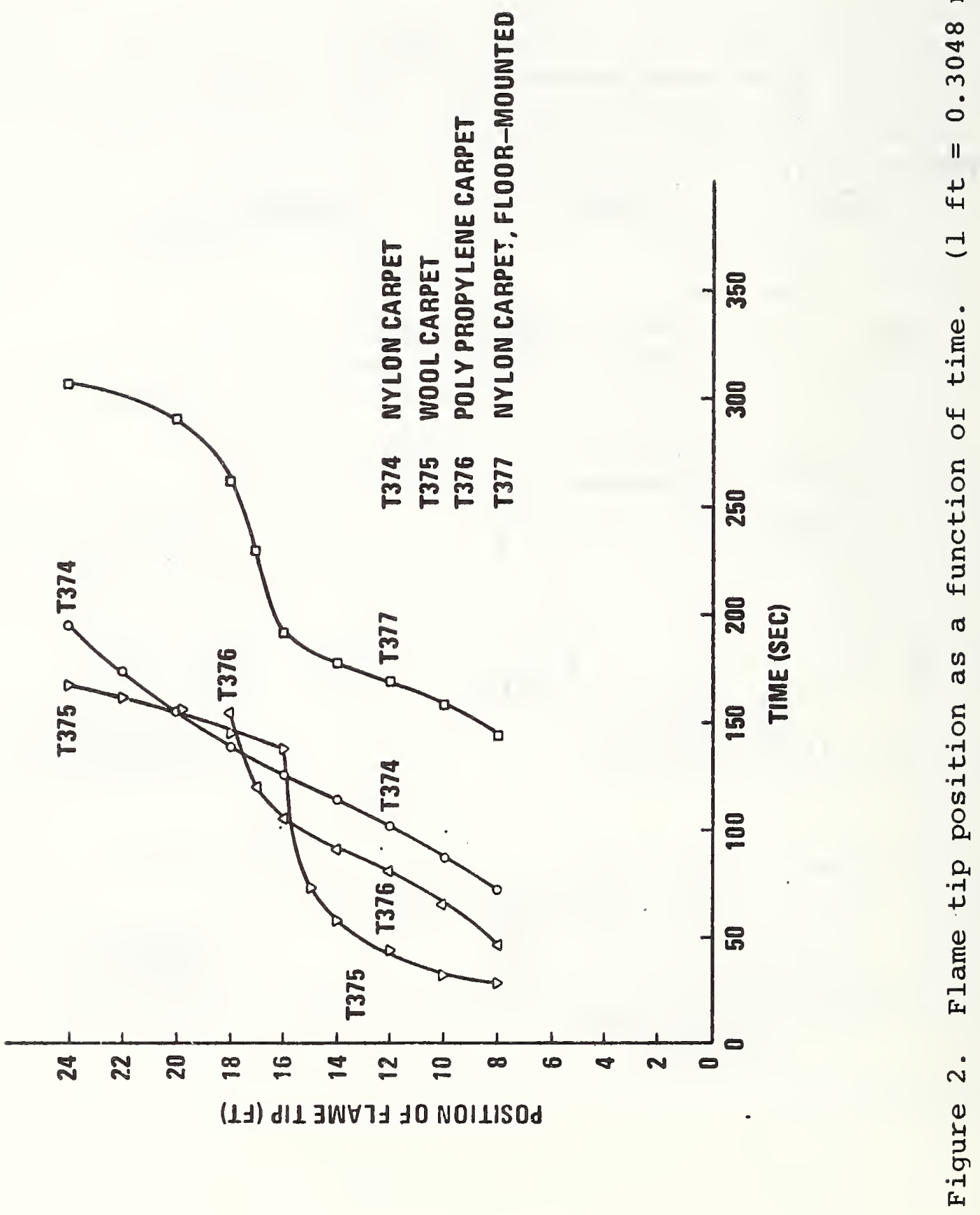




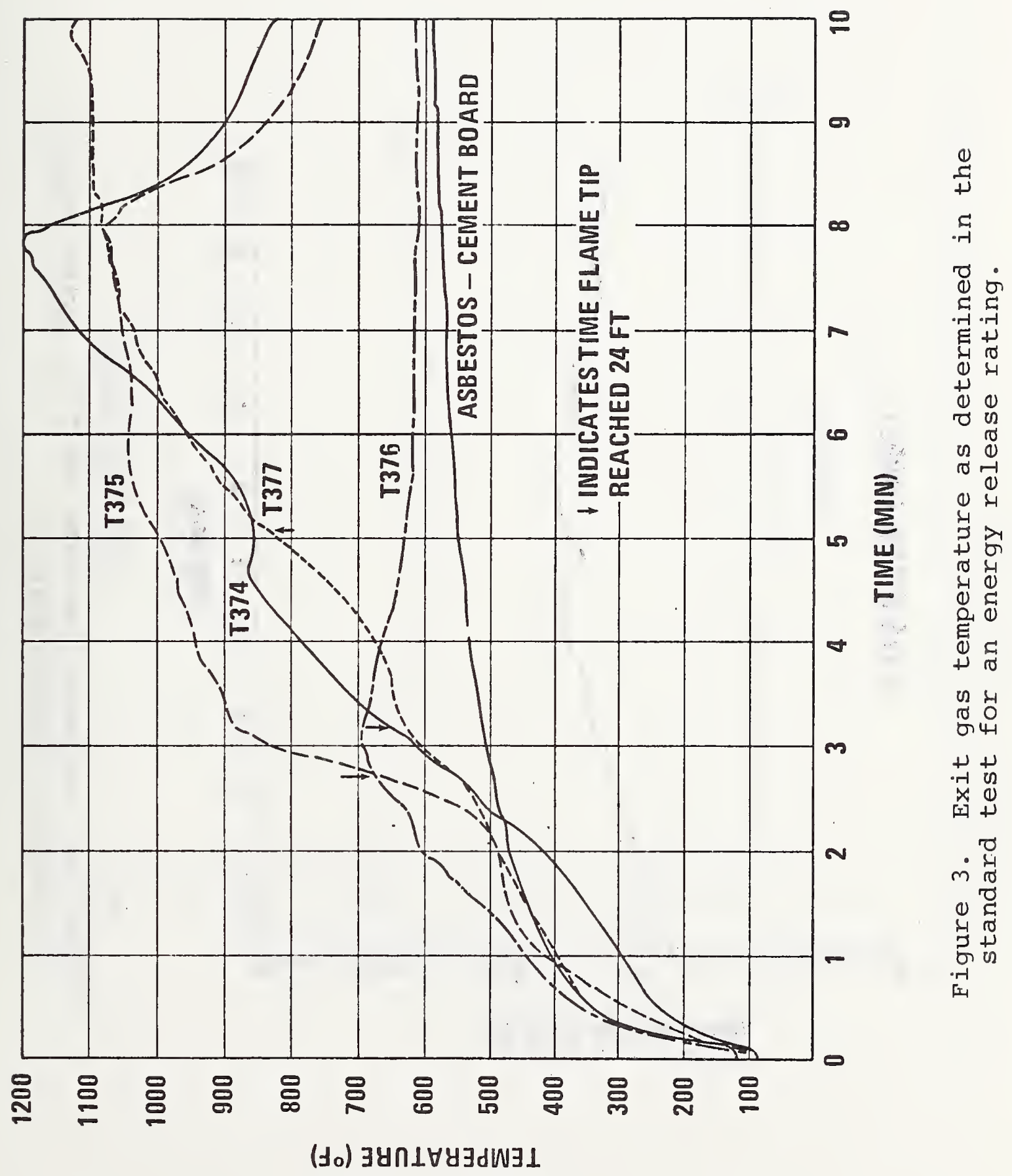




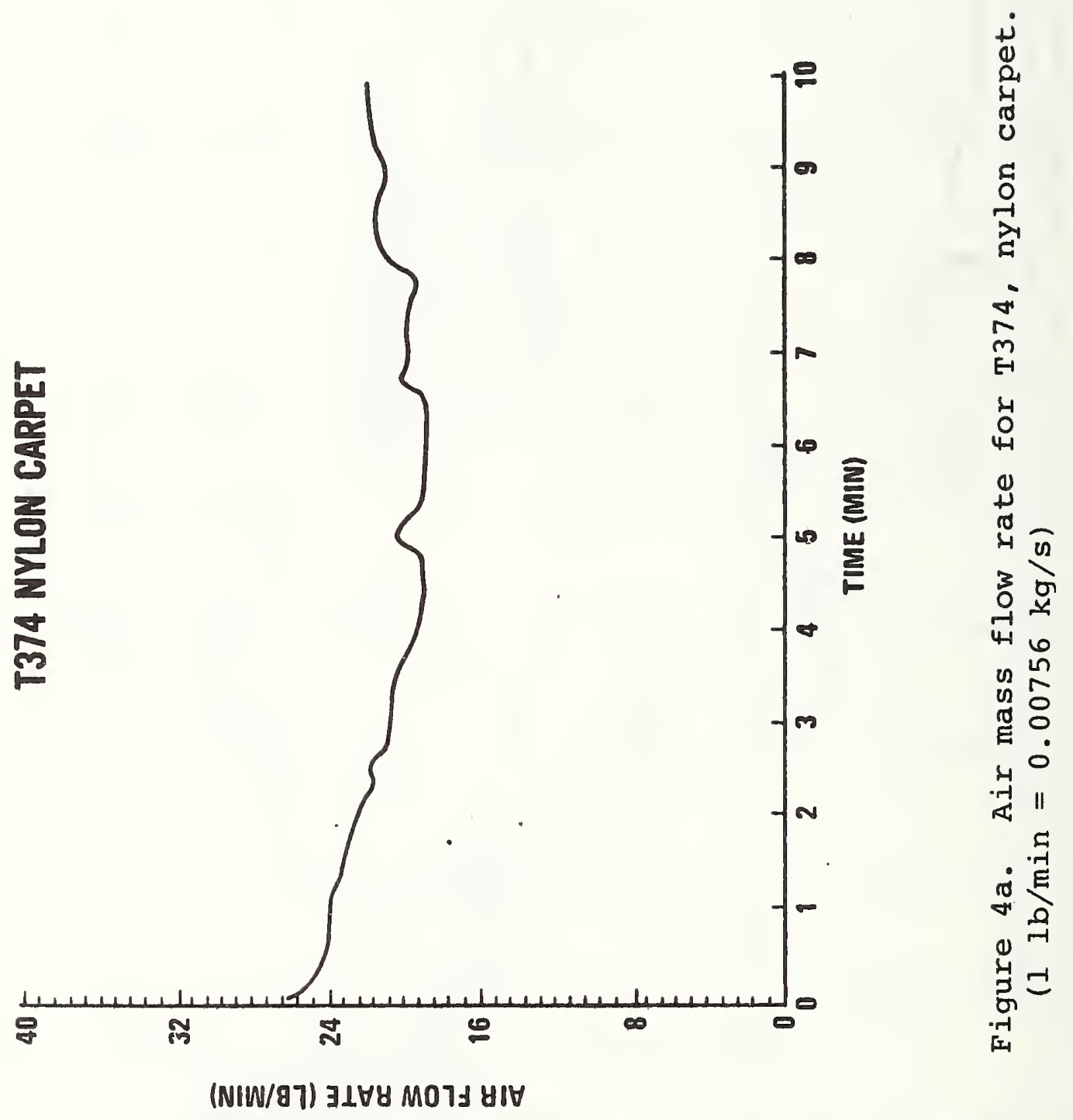



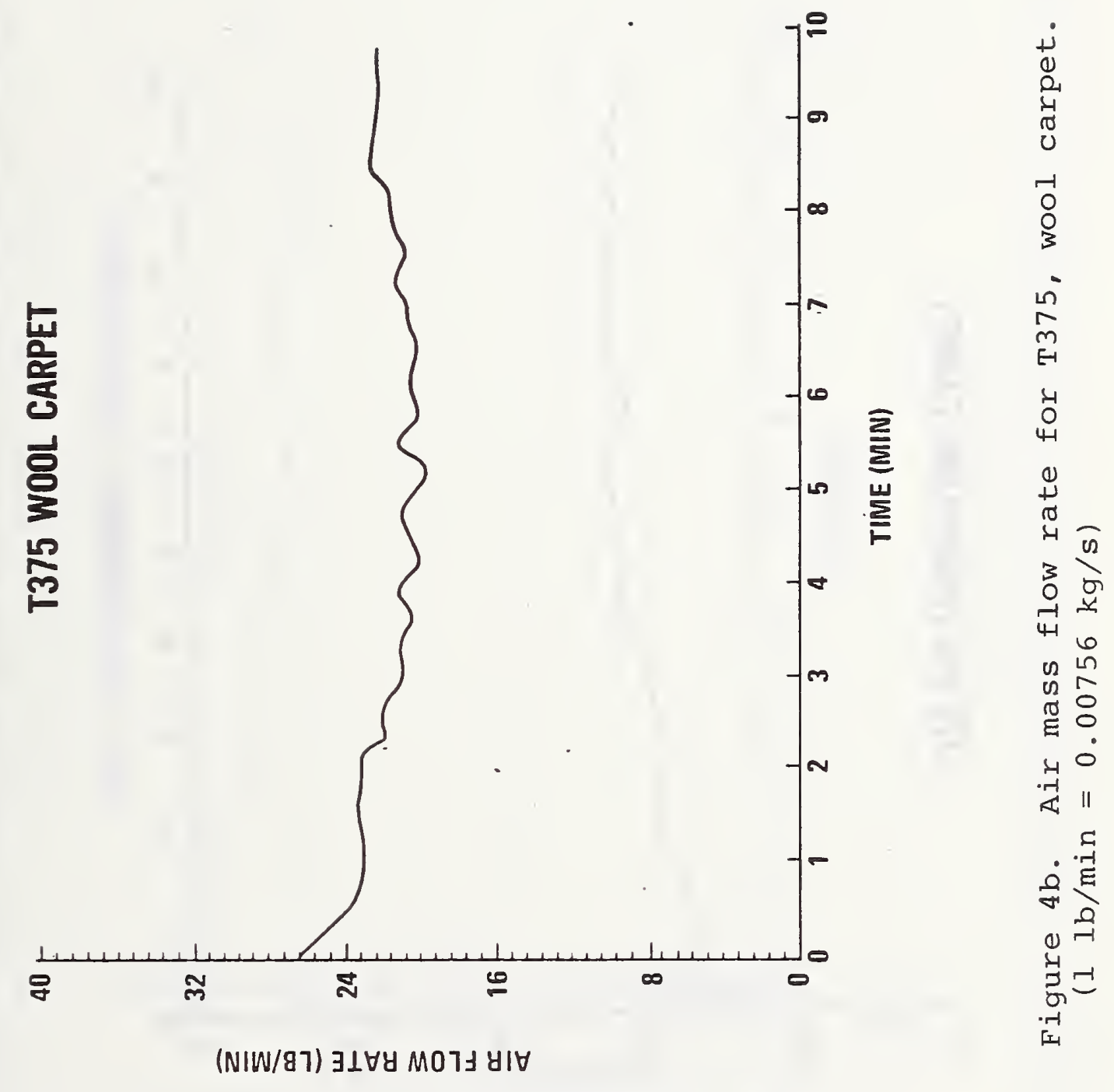


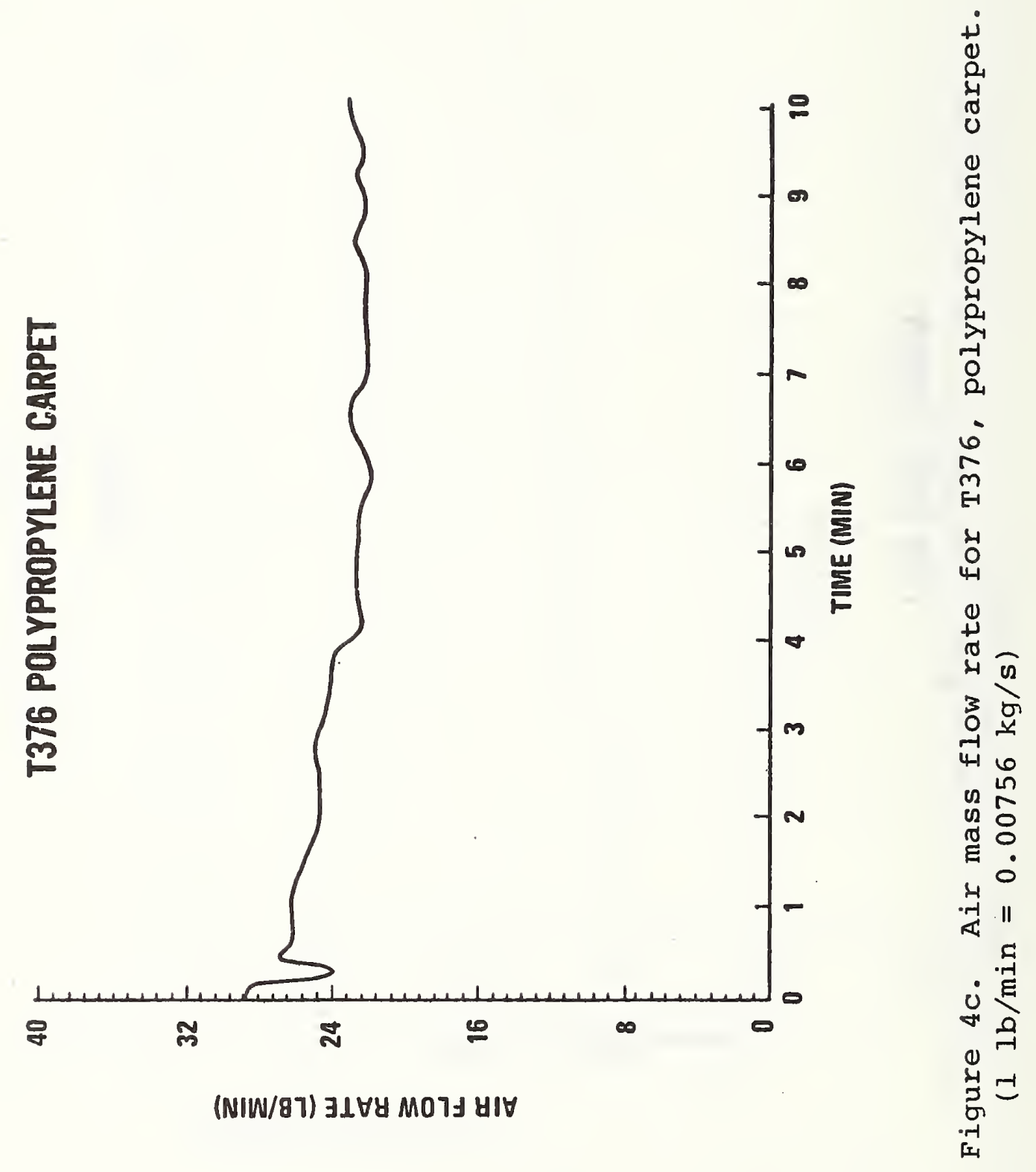




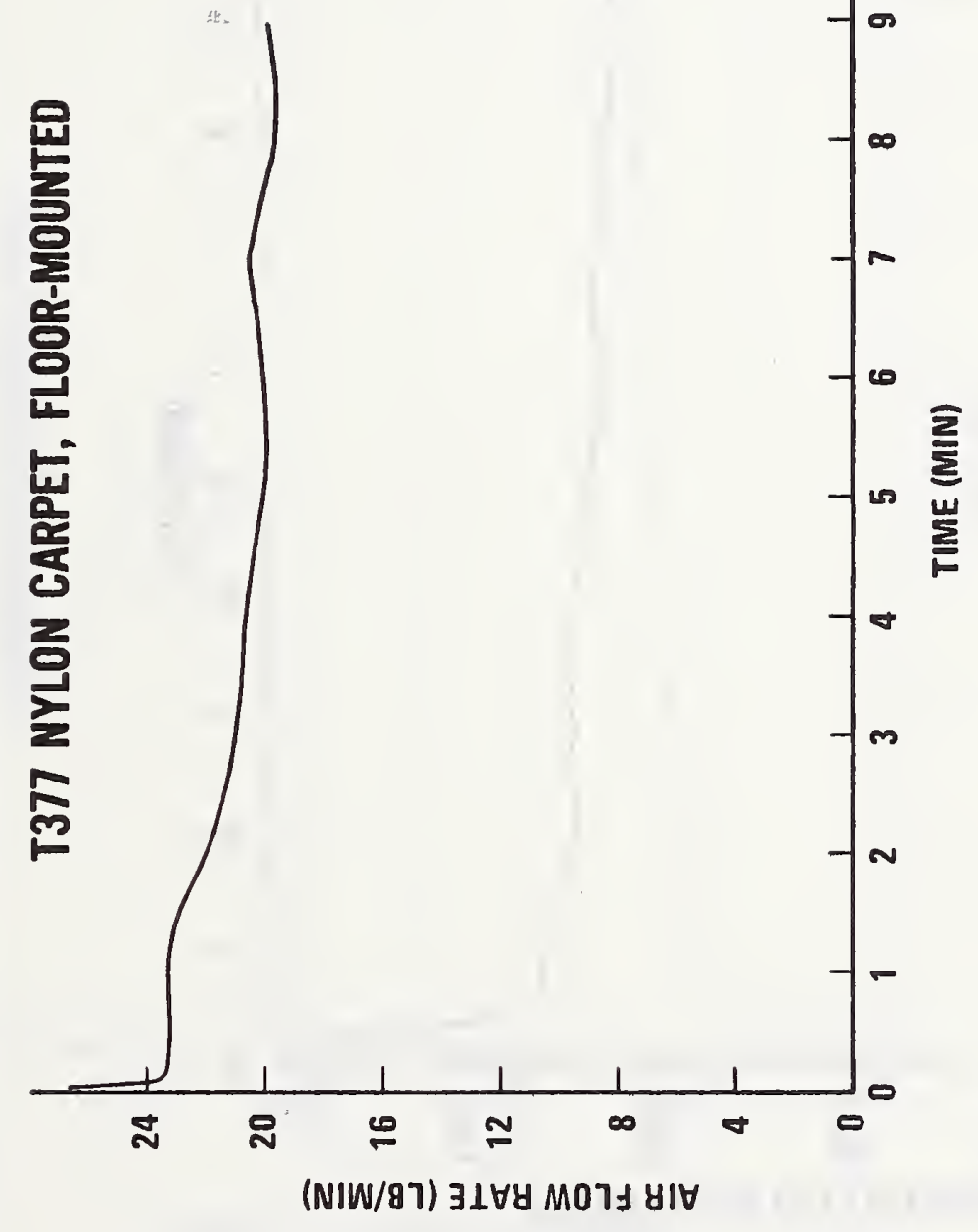

ته

4-

$\uplus$

사

r

돈

n-1

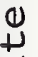

ro

40 उे के

$4-16$

o

U 0

ஸ્

(F)

$4^{\circ}$

.

.

ס

요

矛

II 


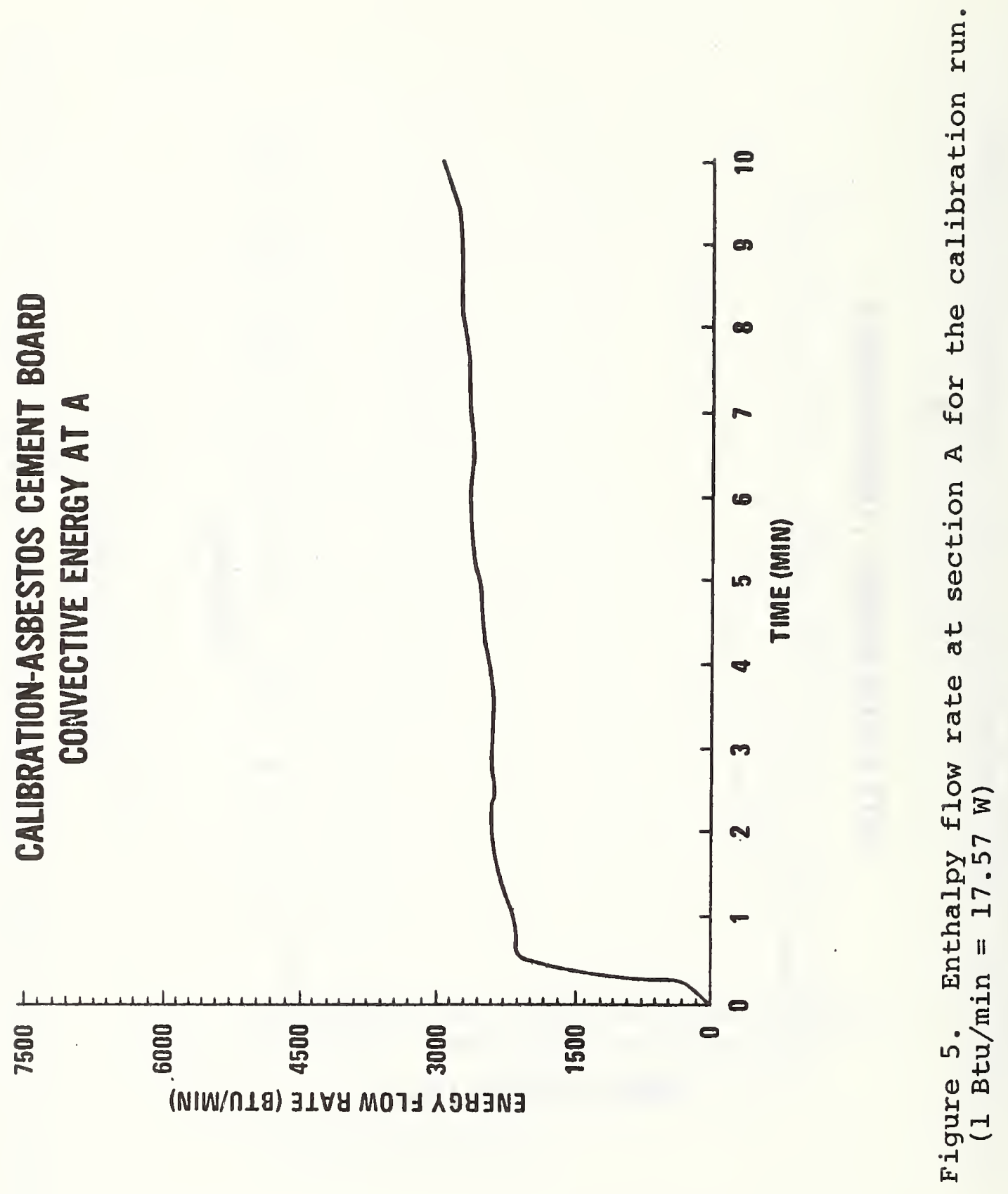




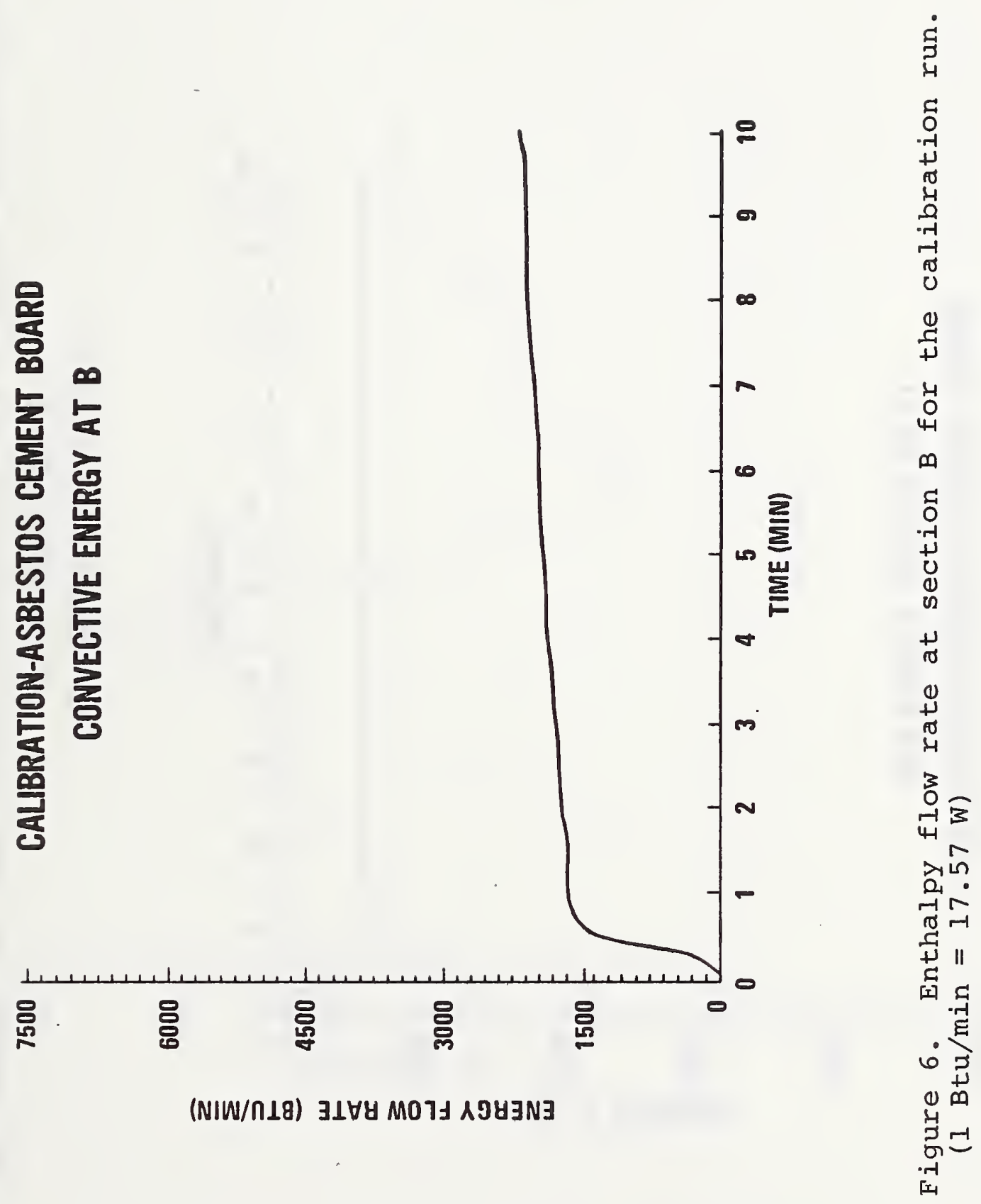




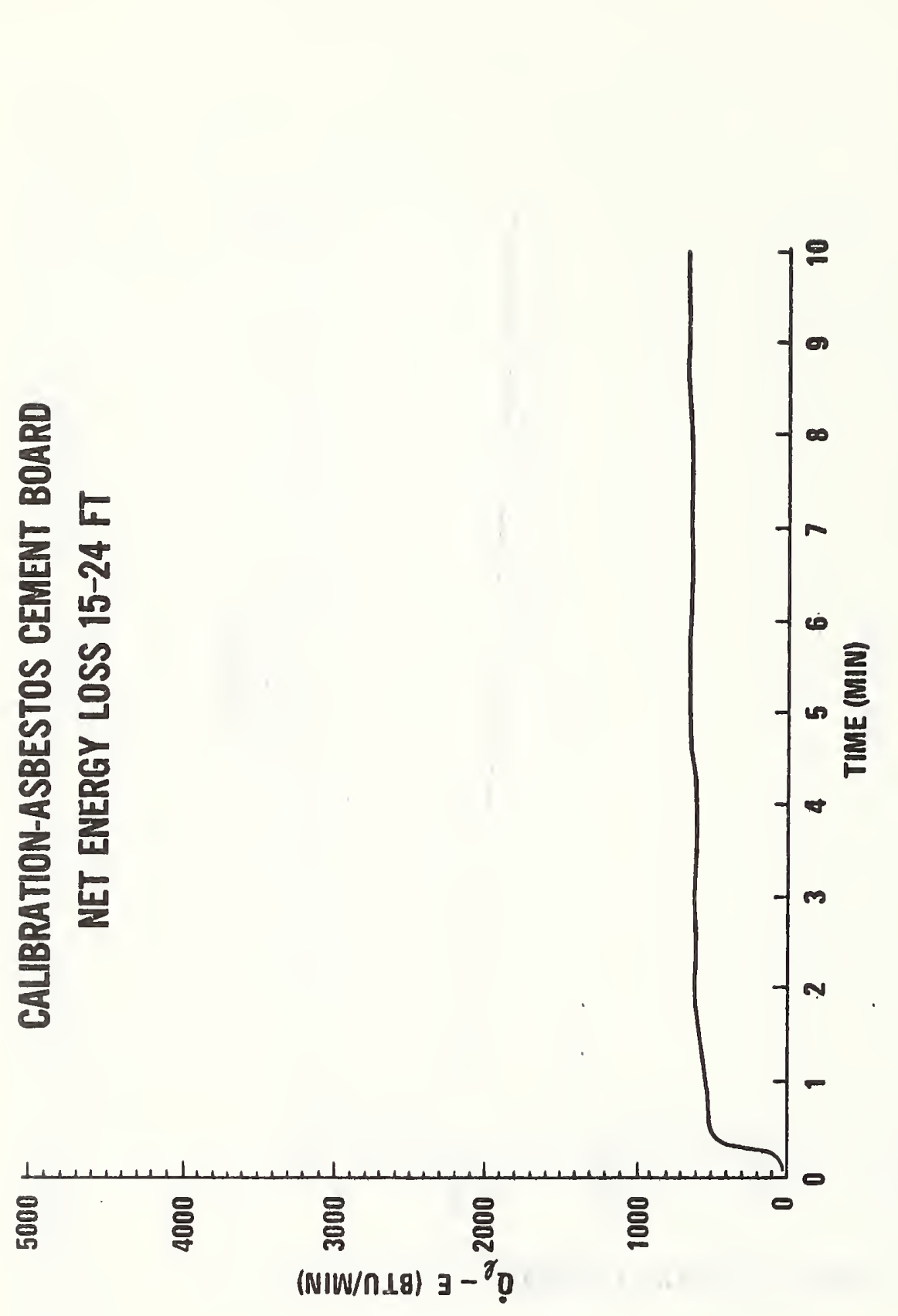

ह

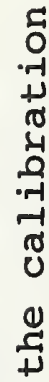

4
0
4

$\infty$

'。

4

I

응

or

मै in

(1)

(1) 1

Z

م 


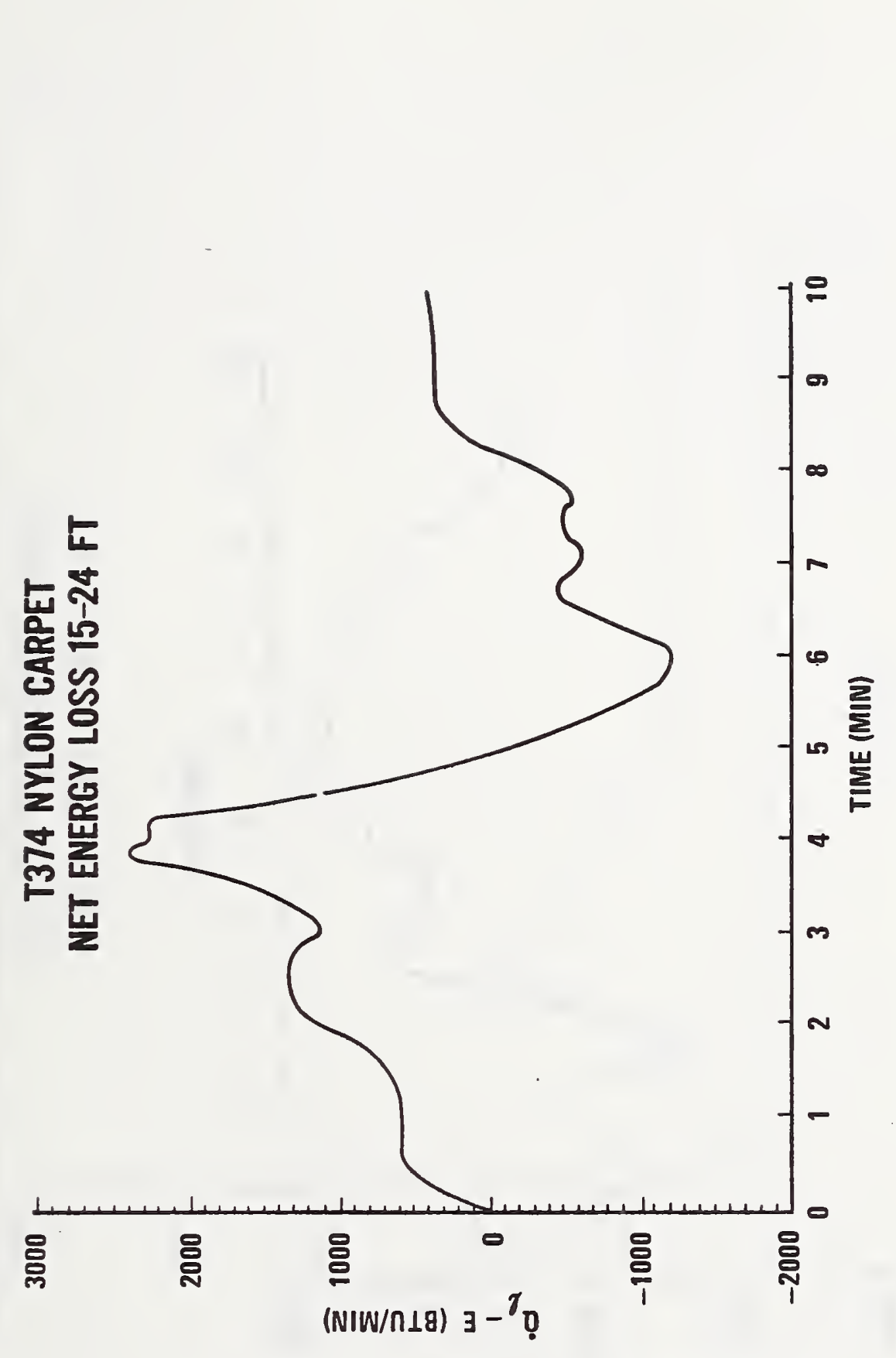

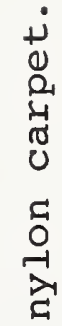

m

ช్ర

$\leftarrow$

0
0
0
0
0
0
0
0

c)

$\frac{1}{3}$

茪

อ

(્)

匆

(2)

U

$\rightarrow 3$

Or

a in

近

+) 11

Z

.

فำ

हु 


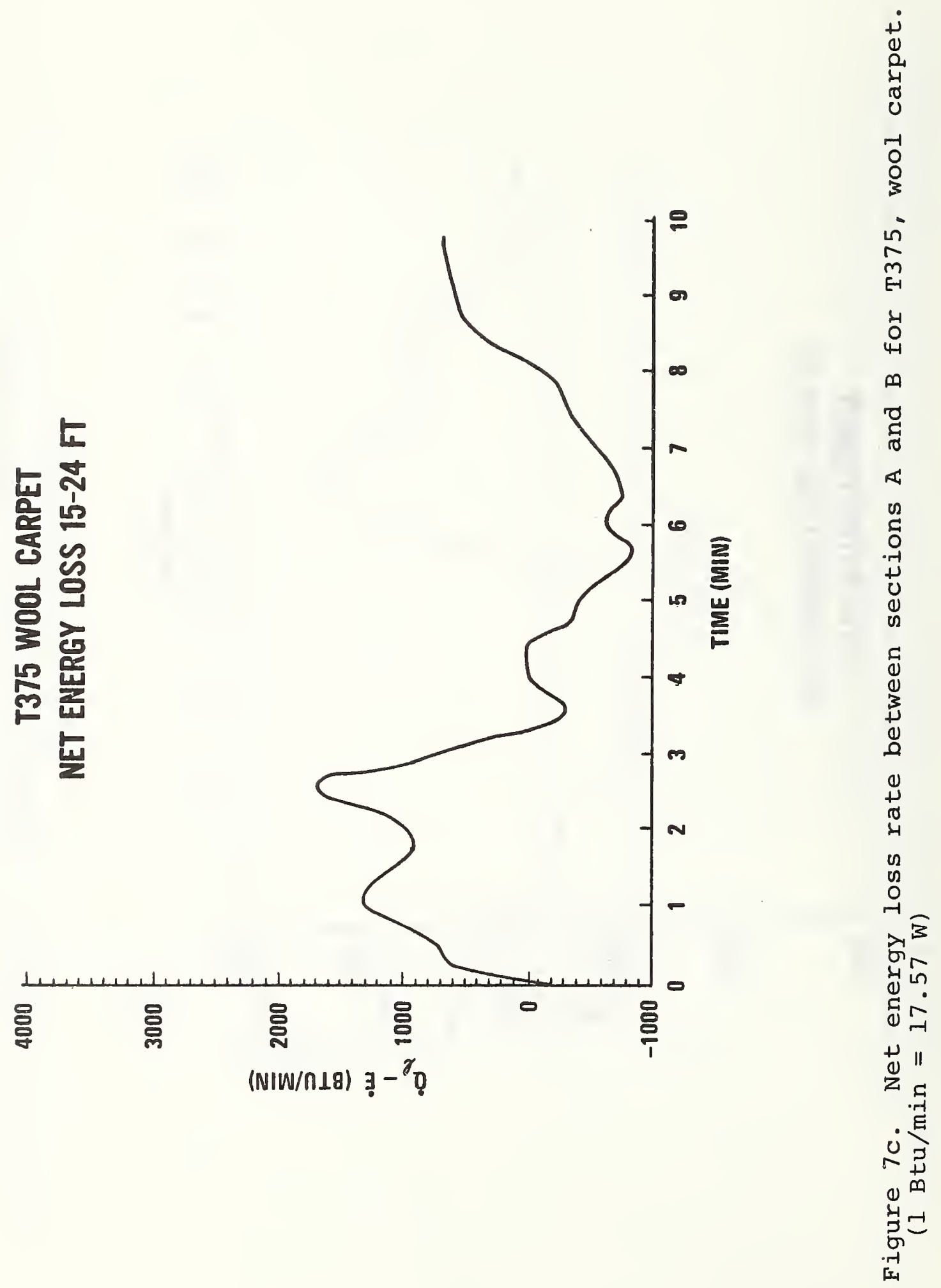




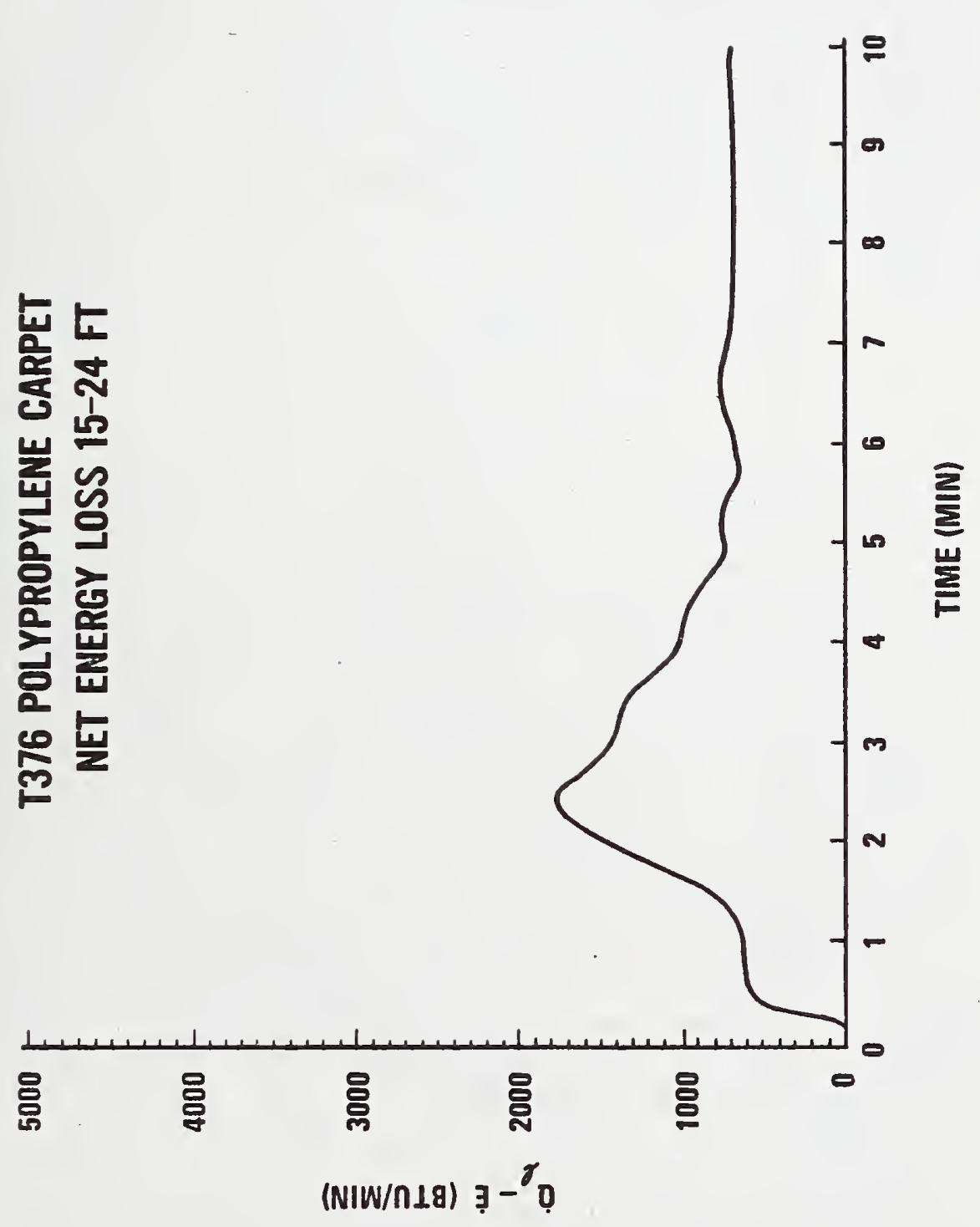

$m$

$\widetilde{3}$

ชิ

in

4

en -1

\&

맫

U.

है

ร

(1)

(1)

$3-1$

0

$0+$

ช

प्र प्र

os 0

on

00

त

$\lambda \overrightarrow{1}$

당

(1) 0

(1) म्न

군

0

.

סิ

E

(1)

든

.-

[4. 
NBS-114A (REV. 7-73)

\begin{tabular}{|c|c|c|c|}
\hline $\begin{array}{l}\text { U.S. DEPT. OF COMM. } \\
\text { BIBLIOGRAPHIC DATA } \\
\text { SHEET }\end{array}$ & $\begin{array}{l}\text { 1. PUBLICATION OR REPORT NO. } \\
\text { NBS IR } 75-705\end{array}$ & $\begin{array}{l}\text { 2. Gov't Accession } \\
\text { No. }\end{array}$ & 3. Recipient's Accession No. \\
\hline \multirow{3}{*}{\multicolumn{3}{|c|}{$\begin{array}{l}\text { 4. TITLE AND SUBTITLE } \\
\text { Thermal and Flow Characteristics of the ASTM } \\
\text { E } 84 \text { Tunnel Test Method }\end{array}$}} & 5. Publication Date \\
\hline & & & September 1975 \\
\hline & & & 6. Performing Organization Code \\
\hline \multicolumn{3}{|c|}{$\begin{array}{l}\text { 7. AUTHOR(S) } \\
\text { James G. Quintiere and James W. Raines }\end{array}$} & $\begin{array}{l}\text { 8. Performing Organ. Report No. } \\
\text { IR } 75-705\end{array}$ \\
\hline \multirow{2}{*}{\multicolumn{3}{|c|}{$\begin{array}{l}\text { 9. PERFORMING ORGANIZATION NAME AND ADDRESS } \\
\text { NATIONAL BUREAU OF STANDARDS } \\
\text { DEPARTMENT OF COMMERCE } \\
\text { WASHINGTON, D.C. } 20234\end{array}$}} & 10. Project/Task/Work Unit No. \\
\hline & & & \begin{tabular}{|l}
4915676 \\
11. Contract/Grant No.
\end{tabular} \\
\hline \multirow{2}{*}{\multicolumn{3}{|c|}{ 12. Sponsoring Organization Name and Complete Address (Street, City, State, ZIP) }} & $\begin{array}{l}\text { 13. Type of Report \& Period } \\
\text { Covered } \\
\text { Final } \\
\end{array}$ \\
\hline & & & 14. Sponsoring Agency Code \\
\hline
\end{tabular}

15. SUPPLEMENTARY NOTES

16. ABSTRACT (A 200-word or less factual summary of most significant information. If document includes a significant bibliography or literature survey, mention it here.)

Five experiments were conducted using an ASTM E 84 tunnel test facility. These included a calibration test, three standard tests involving carpet materials, and one test in which a carpet material was tested on the floor of the duct. In addition to the measurements recorded during a standard test, instrumentation was added to measure inlet air velocity, temperature within the test section of the duct, and heat flux. From these measurements mass and energy balances were determined for each experiment. The results indicate that inlet air mass flow rate dropped during a test and appears to depend on the extent of burning in the duct. The energy balance results indicate that for the calibration run about half of the energy of the gas burner is lost by radiation and convection to the walls in the test section of the tunnel. During combustion of a test specimen, significant energy losses occur in the last 9 feet of the test section even after the flame tip has reached the exit of the tunnel.

17. KEY WORDS (six to twelve entries; alphabetical order; capitalize only the first letter of the first key word unless a proper name; separated by semicolons) ASTM E 84; carpets; energy balance; flame spread; mass balance; test method.

\begin{tabular}{|c|c|c|}
\hline $\begin{array}{l}\text { 18. AVAILABILITY } X \text { Unlimited } \\
\square \text { For Official Distribution. Do Not Release to NTIS }\end{array}$ & $\begin{array}{l}\text { 19. SECURITY CLASS } \\
\text { (THIS REPURT) } \\
\text { UNCL ASSIFIED }\end{array}$ & 21. NO. OF PAGES \\
\hline $\begin{array}{l}\square \text { Order From Sup. of Doc., U.S. Government Printing Office } \\
\text { Washington, D.C. 20402, SD Cat. No.C13 }\end{array}$ & $\begin{array}{l}\text { 20. SECURITY CLASS } \\
\text { (THIS PAGE) }\end{array}$ & 22. Price \\
\hline $\begin{array}{l}\text { 2. Order From National Technical Information Service (NTIS) } \\
\text { Springfield, Virginia 2215I }\end{array}$ & UNCLASSIFIED & $\$ 3.75$ \\
\hline
\end{tabular}


